\title{
Police Practices and the Law- From Arrest to Release or Charge
}

Edward L. Barrett, Jr.*

TVT ITHIN Mrodern urban nations the trend has been in the direction of reliance on the law, particularly the criminal law, as the means of governing wider and wider aspects of human behavior. The days of selfhelp and vigilance committees have gone; each of us has no choice but to rely on the law and the official mechanisms for its enforcement to make life tolerable in our urban society. Progress in creating legal controls has only begun in the international field, but there is a widespread feeling that the science of destruction has so far preceded the science of international law that the nations of the world now must choose between mutual annihilation and law. Current headlines indicate both that the time for choice may be short and that the process of creating a viable international legal order will be incredibly complex and difficult-perhaps calling for a revolution in international political technology even greater and more complex than the revolution in scientific technology that brought us from gunpowder to hydrogen bombs.

Legal controls-both the existing ones within nations and the potential ones between nations-depend for their effectiveness upon widespread respect for and obedience to the law. And this respect and obedience depend in large part on the adequacy of the mechanisms for enforcement of the law. Where enforcement mechanisnis are inadequate, respect wanes and legal controls become impotent. ${ }^{1}$ The basic problem is the same at every level.

Because of the necessity of maintaining respect for the law, Western societies have shown an increasing concern with the fairness and legality of the methods by which the law is enforced. In our country police procedures and methods evolved over a long period of time during which legal controls over police conduct were in practice, if not in theory, minimal. ${ }^{2}$ Furthermore, they evolved and continue to exist in a completely fragmented system with thousands of autonomous units subject to no overall administrative supervision or control. ${ }^{3}$ In default of any other general controlling

* Professor of Law, University of California School of Law, Berkeley. I am indebted to the Walter E. Meyer Research Institute of Law for a grant that assisted in this inquiry.

1 See generally Rerre, THE BLIND Eye of HistorX (1952).

${ }^{2}$ See HopkIns, OUR Lawdess Porice 26-27 (1931). For the English experience in the gradual development of informal controls, see Devitr, The Crmannax Prosecution IN England (1958) [hereinafter cited as Deving]; Williams, Questioning by the Police: Some Father Points_2 [1960] CrmM. L. REv. (Eng.) 352, 353.

3 Sarth, Police Sxstexrs In the United States 20-23 (2d rev. ed. 1960). 
authority, the courts are attempting to fill this vacuum by asserting controls over police conduct. ${ }^{4}$ Judicial control, which did not begin to be a significant factor until the 1920's, is now expanding rapidly. Initial concern was with search and seizure ${ }^{b}$ and with brutality that led to confessions. ${ }^{7}$ Increasing attention is now being given to arrest policy and the handling of persons arrested..$^{8}$ More generally, the courts are concerned

4 See Mapp v. Ohio, 367 U.S. 643,660 (1961): "[W]e can no longer permit it [the right to privacy embodied in the fourth amendment] to be revocable at the whim of any police officer who, in the name of law enforcement itself, chooses to suspend its enjoyment."; People v. Cahan, 44 Cal. 2d 434, 445, 282 P.2d 905, 911 (1955): "We have been compelled to reach that conclusion [that evidence obtained in violation of constitutional guarantes is inadmissible] because other remedies have completely failed to secure comphance with the constitutional provisions on the part of police officers with the attendant result that the courts under the old rule have heen constantly required to participate in, and in effect condone, the lawless activities of law enforcement officers."

5 During its 1960 Term alone the Supreme Court of the United States wrote opinions in ten cases dealing with the legality of activities of state and federal police. Marcus v. Search Warrant, 367 U.S. 717 (1961); Mapp v. Ohio, 367 U.S. 643 (1961); Culombe v. Connecticut, 367 U.S. 568 (1961) ; Reck v. Pate, 367 U.S. 433 (1961); Coppola v. United States, 365 U.S. 762 (1961) ; Chapnian v. United States, 365 U.S. 610 (1961) ; Rogers v. Richmond, 365 U.S. 534 (1961) ; Silverman v. United States, 365 U.S. 505 (1961); Wilson v. Schnettler, 365 U.S. 381 (1961); Monroe v. Pape, 365 U.S. 167 (1961). On the Supreme Court history see generally Allen, Federalism and the Fourth Amendment: A Requiem for Wolf, 1961 SvP. Cr. REv. 1, 2-3.

Since the decision in People v. Cahan, stipra note 4, the appellate courts in California have decided hundreds of cases involving the legality of police practices. For a hist of those cases relating to searches and seizures and probable cause to arrest that were decided up to January 1 , 1960, see Martin, Probable Cause To Arrest and AdmissibIitiy of Evidence (rev. ed. 1960).

${ }^{B}$ Sustained judicial attention to the problem began with Weeks v. United States, 232 U.S. 383 (1914), holding that evidence obtained by federal officers by illegal searches should be excluded fron use in the trial of the defendant. For a discussion of the early cases see Fraenkel, Concerning Searches and Seizures, 34 HARv. L. REv. 361 (1921). State courts gradually followed suit until by 1960 the federal practice was followed in 26 states. See Elkins v. United States, 364 U.S. 206, 224-32 (1960). In 1961 the United States Supreme Court held that all states were compelled by the fourteenth amendinent to follow the federal rules of exclusion. Mapp v. Ohio, 367 U.S. 643 (1961). See generally MAGUIRE, EvIDENCE of GuILT 167-240 (1959); MCCORATCK, EvIDENCE 291-301 (1954); Allen, Federalism and the Fourth Amendment: A Requiem for Wolf, 1961 Sup. CT. REv. 1.

7 For a discussion of the carly cases dealing with the problem as a matter of common-law evidence doctrine, see Annot., 24 A.L.R. 703 (1923). The doctrine that the due process clause prohibits the use of confessions obtaincd by force began with Brown v. Mississippi, 297 U.S. 278 (1936). See generally MaguIRE, EvIDENCE OF GuIIT 107-54 (1959).

8 See Culonbe v. Connecticut, 367 U.S. 568 (1961); Coppola v. United States, 365 U.S. 762 (1961) ; Spano v. New York, 360 U.S. 315 (1960); Crooker v. California, 357 U.S. 433 (1958); Mallory v. United States, 354 U.S. 449 (1957) ; People v. Garner, 57 A.C. 151, 367 P.2d 680, 18 Cal. Rptr. 40 (1961); People v. Hamilton, 359 Mich. 410, 102 N.W.2d 738 (1960); People v. Noble, 9 N.Y.2d 571, 175 N.E.2d 451, 216 N.Y.S.2d 79 (1961) ; People v. Waterman, 9 N.Y.2d 561, 175 N.E.2d 445, 216 N.Y.S.2d 70 (1961) ; MAGUIRE, EvIDENCE OF GUIIT 155-66 (1959); Coakley, Restrictions in the Law of Arrest, 52 Nw. U.L. REv. 2 (1957) ; Foote, Safeguard's in the Law of Arrest, 52 Nw. U.L. Rev. 16 (1957); Kamisar, Illegal Searches or Seizures and Contemporaneous Incriminating Statements: A Dialogue on a Neglected Area of Criminal Procedure, 1961 U. ILI. L.F. 78. 
with the dangers to respect for the law if official lawbreaking is countenanced. What was said by Mr. Justice Brandeis in dissent in 1928 has become the central theme of modern judicial pohicy:

Decency, security and liberty alike demand that government officials shall be subjected to the same rules of conduct that are commands to the citizen. In a government of laws, existence of the government will be imperilled if it fails to observe the law scrupulously. Our Government is the potent, the ommipresent teacher. For good or for ill, it teaches the whole people by its example. Crime is contagious. If the Government becomes a lawbreaker, it breeds contempt for law; it invites every man to become a law himself; it invites anarchy. To declare that in the administration of the criminal law the end justifies the means-to declare that the Government may commit crimes in order to secure the conviction of a private criminal -would bring terrible retribution. Against that pernicious doctrine this Court should resolutely set its face. ${ }^{9}$

But this substantial increase in judicial pressures to compel police to adjust their practices to conform with law has created new problems and tensions. No one disputes the simple proposition that the police must obey the law. ${ }^{10}$ The difficulty arises because in many areas there is wide disagreement about what the law is that the police must obey - and even wider disagreement about what rules governing police are consistent with adequate law enforcement under modern conditions. ${ }^{11}$ Of course, it is agreed on all sides that police brutality and police corruption should not be tolerated. ${ }^{12}$ Disagreement in this area is primarily about the extent to which such abuses exist; ${ }^{13}$ their elimination is a principal objective of the leaders in law enforcement today. ${ }^{14}$ But when the question shifts to determining

9 Olmstead v. United States, 277 U.S. 438, 485 (1928). See also Mapp v. Obio, 367 U.S. 643, 659 (1961) ; Elkins v. United States, 364 U.S. 206, 222-23 (1960) ; People v. Cahan, 44 Cal. 2d 434, 446, 282 P.2d 905 (1955); Paulsen, The Exchusionary Rule and Miscondact by the Police, 52 J. Crar. L., C. \& P.S. 255 (1961).

10 See, e.g., Wirson, Parger on Police 125 (1957). But cf. Saitre, Police Systears In THE UNITED States 323-28 (2d rev. ed. 1960).

11 Compare Wilson, Police Arrest Privileges in a Free Society: A Plea for Modernization, 51 J. Crns. L., C. \& P. S. 395 (1960), with Foote, The Fourth Amendment: Obstacle or Necessity in the Law of Arrest?, 51 J. Crom. L., C. \& P. S. 402 (1960). See also SymposiumAre the Courts Handcuffing the Police?, 52 Nw. U.L. REv. 1-89 (1957).

12 See ARTHUR \& Caputo, Interrogation for Investigators 199-207 (1959); Inbau, "Fair Play" in Crininal Investigations and Prosecutions, Northwestern University TriQuarterly (Whiter, 1961), p. 3, at 6; Roberts, Paradoxes in Law Enforcement, 52 J. CREs. L., C. \& P. S. 224 (1961); Scott, The Mallory Decision and The Vanishing Rights of Crime Victins, 4 Potice 61, 62-63 (May-June 1960). Of course, individuals in police service may take a different view. See McAulister, The Kind of A GuY I AM (1957); SMITH, Police Systems IN THE UNITED STaTES 9-13, 324-28 (2d rev. ed. 1960).

13 For a current appraisal see U.S. Comar'N on Crvil RroHts, Justice 5-28 (1961); cf. Santre, Police Systears IN THE United States 324-28 (2d rev. ed. 1960).

14 See the statement by J. Edgar Hoover quoted in Elkins v. United States, 364 U.S. 206, 218 n.8 (1960). 
the legality of the methods used by policemen honestly attempting to enforce the law, disputes rage. ${ }^{15}$

The governing law has always been broad and general. In large part it has been based on rules developed by the courts and expressed in constitutions and statutes during the 17 th and 18 th centuries when society was simpler and the functions of criminal investigation had not been transferred from the magistrates to the professional police. ${ }^{16}$ Until recently this law had only a limited practical effect upon police activities; police adjusted to the changing conditions facing them in our modern society by developing their own code of "accepted" police practices as the standard for good police conduct. ${ }^{17}$ Now, with relative suddenness, the police are finding many of these accepted practices declared illegal and unconstitutional. What is worse, from the police point of view, these new decisions are based in the main on the assumption that the law has always been that wayfixed by the Constitution or settled by our common-law heritage-with little or no conscious examination of the rules to determine whether they strike a reasonable balance between the conflicting clains of public order and individual liberty in the context of urban America in mid-twentieth century. ${ }^{18}$

Hence new tensions are arising. Law enforcement agencies and courts, instead of cooperating toward common goals, are expending increasing amounts of energy in fighting each other. All too often name-calling becomes the substitute for reason. Appellate courts denounce police for "deliberate, flagrant acts" in violation of the Constitution and law, for engaging in that "lawless although efficient enforcement of the law" that is but a short step from the "police state." ${ }^{\text {Po }}$ Police, finding that each new judicial restriction on practices long regarded as reasonable and necessary counpounds the difficulty of coping with an ever-increasing, ever-changing crime

15 See the authorities cited note 11 stupra. See also Coalley, Law and Legislative Committee, Cal. Peace Officer, July-Aug. 1957, C-6, at C-8:

They say that we want the right to knock doors down to obtain evidence. That is a lot of bunk, and pure poppycock. We don't want any such things. I am sure that no right thinking peace officer, or district attorney wants to, or would condone or approve the knocking down of doors, and the illegal obtaining of evidence, but there are times in the course of our work, when in hot pursuit of the criminal, or in the hot pursuit of the crime-a murder, a kidnapping, a robbery, that the policeman follows froin one clue to another, and in good faith, because he is doing his job as he sees it, an honest conscientious job.

16 See the discussion in the text at notes 29 to 48 infra.

17 For the situation as it existed in California in 1955 see Barrett, Exclusion of Evidence Obtained by Illegal Searches-A Comment on People vs. Cahan, 43 CaLIr. L. Rev. 565, 569-78 (1955).

${ }^{18}$ For a recent example, see Henry v. United States, 361 U.S. 98 (1959).

19 People v. Calnan, 44 Cal. 2d 434, 438, 447, 282 P.2d 905, 907, 912 (1955). 
burden, react with a violence born of frustration. Decisions are characterized as "catastrophic as far as efficient law enforcement is concerned," and courts are denounced as "unwittingly" serving "the cause of those who seek to create impotence in the administration of criminal justice as one means to their ideological end." ${ }^{21}$ Down this road lies only chaos. And to revert to the broader context within which this article began, what hope is there for the creation of an enforceable international legal order, if our domestic institutions provide such a sorry spectacle?

Chaos can be averted only if immediate and widespread attention is given to resolving the fundamental problems that underhe current conficts. Public attention-particularly by legislatures, courts, law enforcement agencies, scholars, and the media of public information-must be given to the tremendously difficult problem of determining in dêtail just what powers sliould be entrusted to the police for the purpose of enforcing the law. The gulf between the law on the books and the law in action must be bridged-not necessarily by conforming the practice to the law, but by determining instance by instance those rules that will maximize the liberty of citizens generally. And this task cannot be properly accomplislied if we start with the assumption that "law enforcement is forever at odds with civil liberty."22 Liberty is equally lost whether the citizen is left to the mercy of an overzealous policeman or a trigger-liappy lioodlumn..$^{23}$ Nor can we safely regard the problem of private lawlessness as secondary to that of public lawlessness on the assumption that the "basic political problem of a free society is the problem of controlling the public monopoly of force." ${ }^{24}$ History lias too often demonstrated that a direct route to loss of freedom - to dictatorial government-may be that of failure to curb private lawlessness. ${ }^{25}$ Hitler's rise to power was facilitated by the failure of the German government to control the riotous, illegal acts of his supporters. ${ }^{28}$ American cities have suffered periods when the control over government exercised by organized criminals lias stripped citizens of the protection of

20 WIISON, PARKER ON POLTCE 114 (1957).

21 Scott, The Mallory Decision and The Vanishing Rights of Crime Victims, Police, May-June 1960, p. 61.

22 BarTe, The PRICE of Liberty 19 (1961).

23 In 1751 Henry Fielding, in An Enquiry into the Causes of the Late Increase of Robbers, Etc., observed: "If I am to be assaulted, and pillaged, and plundered; if I can neither sleep in my own house nor walk the streets, nor travel in safety; is not my condition almost equally bad whether a licensed or unlicensed rogue, a dragoon or a robber, be the person who assaults and plunders me?" 13 THE COMPIETE WORKS OF HENRY Fintone, Esof 5 (Henley ed. 1903). See Barrett, Book Review, 23 U. CHI. L. Rev. 730, 732 (1956).

24 Paulsen, The Exchusionary Rule and Misconduct by the Police, 52 J. Cram. L., C. \& P. S. 255,264 (1961).

25 See generally ReIrH, Tae Brind Eye of History (1952).

${ }^{26}$ See generally ShIRER, The Rise and FaLl of tHe Third Reich (1960). 
the law. ${ }^{27}$ Recent episodes involving racial tensions have demonstrated anew the lesson of history that mob rule destroys individual liberty. ${ }^{28}$

In this article attention will be focused on one area where the gap between law and practice appears to be very great. The main question to be discussed is that of the role played by the police and prosecuting officials in determining which persons arrested for serious offenses shall be brought before courts and formally charged with commission of offenses. Is the screening function prinarily for the courts? Is post-arrest police investigation to determine whether to charge or release the arrested person a legal procedure? A necessary procedure? What are the roles actually performed by police and prosecutors, on the one hand, and courts, on the other hand, in the screening process? Subsidiary questions will also be considered in less detailed fashion: Assuming that post-arrest police investigation is necessary, what restrictions does the law place on such investigation? What are presently accepted practices in such investigations? To what extent should such practices be legalized?

I

THE IAW AND THE PRACTICE-IN GENERAL

The basic structure of our law in this area comes from England. The broad outlines are traceable to the period in English history when there were no police ${ }^{29}$ and when law enforcement responsibilities were vested in the justices of the peace. The justices were first established in England in 1326 with the primary duty "to keep the peace."30 By 1360 they were empowered "to take and arrest all those that they may find by indictment, or by suspicion and to put them in prison." ${ }^{\prime 31}$ Under the governing statutes the justices "were, in fact, the over-riding police authority in each county." ${ }^{32}$ Stephen reported that under the procedure established in the 16th century the justice

acts the part of the public prosecutor. . . . Under the acts of Philip and Mary the accused person is to be examined. This meant that lie was to be fully questioned as to all the circumstances connected with his supposed

27 See Moynihan, The Private Government of Crime, The Reporter, July 6, 1961, p. 14.

28 See U.S. Comar's on CIVII RIGHTs, Justrce 29-44 (1961). For an enlightening discussion of the problems faced by police in preserving law and order in these situations see the guide for law enforceinent officers, With Justice for $A l l$, published jointly in 1959 by the Anti-Defamation League of B'nai B'rith and the International Association of Chiefs of Police.

29 The constable in early England was in no sense a professional policeinan. The office was unpaid, persons liable to serve were appointed in rotation, and the duties of the office were regarded as so onerous that persons appointed often avoided service by liring substitutes. See Coatman, Potice 25 (1959); Devitn, 5 (1958); 2 Radzinowicz, A History of Engtish Crommar Law 181-86 (1956).

30 Justices of the Peace, 1327,1 Edw. 3, c. 16.

31 The Justices of the Peace Act, 1360, 34 Edw. 3, c. 1.

32 Osborne, JUstices of TFE PeACE 1361-1848, at 19 (1960). 
offence.... [T] he exammation of the witnesses and the recording of their depositions was intended only for the information of the court. The prisoner had no right to be, and probably never was, present. ... [T] he depositions were to be returned to the court, but there is evidence to show that the prisoner was not allowed even to see them.... The object [of the statutes of Philip and Mary] is to expose and detect a man assumed to be guilty. ${ }^{33}$

To some extent, at least, this English practice was brought to colonial America. Massachusetts gave investigatory powers to its magistrates, ${ }^{34}$ and as late as $\mathbf{1 8 5 0}$ the New York Code Commissioners expressed concern over the extent of the discretion vested in the magistrate. ${ }^{35}$ However, in some American colonies the English practice was not adopted ${ }^{36}$ and as Professor Moley reported, "the early development of the county prosecutor as an aggressive agent of law enforcement, and the power and prestige of the sheriff in all frontier communities, probably prevented the justice of the peace and the city magistrates from assuming much importance as investigators of crinies and suspected criminals."37

At any rate, in England shortly after the advent of professional police in the $1830{ }^{\prime}{ }^{38}{ }^{38}$ and at about the same time in this country, ${ }^{39}$ the justices of the peace gave up their law enforcement duties and confined themselves to the more judicial role familiar to us today. Maitland colorfully described the transition as it took place in England:

Even in 1829 when "a new police force" for "the Metropolitan Police District" was formed, this was done by establishing in Westminster one inore

33 I Stepren, A Hrstory of the Criminal Law of England 221 (1883). The extent to which the justices combined the functions of detectives, prosecutors, and judges is strikingly illustrated by Stephen's description of an actual case. Id. at 223. See the episodes detailed in Grant, Our Common Law Constitution, 40 B.U.L. Rev. 1, 10-13 (1960). See also 1 CHITTY, Crominal Law 72-92 (1826); 1 Holdsworth, A History of English Law 296 (7th ed. 1956) ; 5 Holdsworth, A History of English Law 191 (1927) ; MIITON, IN SOMe AUthorITY-THE ENGLISH MAGistracY 15, 28-34 (1959).

34 HASKINS, LAW AND AUTHORITY IN MASSACHUSETTS 174-75, 200 (1960).

35 Comanisstoners on Practice and Pieadings, Code of Crtmonal Procedure of the STATE OF NEW YORK 84-87 (1850).

36. See, e.g., Henting, Virginia Justice 132 (1795).

37 Moley, Our Cramitax Courts 20 (1930).

38 Devin 7-8; 1 Holnsworth, A Hrstory of ENgirsh Law (7th ed. 1956). For a brief description of the turmoil that led to the creation of the professional police in England, see Reitr, TeE BLIND Eye of History 130-53 (1952).

39 Moley, OUR Crominax Courts 20 (1930). For an indication that the transition in the role of the justices did not coune sharply in this country, see People v. Smith, 1 Cal. 9 (1850); Bismor, Crasrinal Procedure 446-49 (1866). As late as 1896 the United States Supreme Court upheld the use in a federal criminal trial of a statement (not a confession) taken by a United States Commissioner under circumstances described by the Court as follows: "Tt is true that, while he was not sworn, he made the statement before a commissioner who was investigating a charge against him, as he was informed; he was in custody but not in irons; there had been threats of mobbing him the night before the examination; he did not have the aid of counsel; and he was not warned that the statement might be used against him or advised that he need not answer." Wilson v. Umited States, 162 U.S. 613, 624 (1896). 
police "office," provided with two paid justices of the peace, who, under the Home Secretary, were to rule the new constabulary. In 1839 these two "justices" receive the new name of "Commissioners of Pohce of the Metropolis;" the judicial and executive duties comprised in the old conservation of the peace fall apart, and we are left with learned magistrates and gallant commissioners. ${ }^{40}$

Under the system as it existed in England prior to this transition the . law properly recognized the magistrate as the key figure. The normal pattern was for private citizens to complain to the magistrate of criminal acts and for the magistrate to decide whether to arrest the suspected persons. Since the magistrate could not be expected to make all such arrests personally, he often issued warrants, which would delegate the authority to arrest to constables or other persons. Once the arrests were made the magistrate would then personally conduct the interrogation of the defendants and the other investigation necessary to decide whether sufficient grounds existed to hold them for trial. ${ }^{41}$

When the magistrate ceased to be an investigator and a prosecutor and was confined to judicial functions, new questions arose. It was obvious that someone had to assume his old functions. In order for the magistrate to determine whether the defendant should be held for trial, someone had to gather the relevant evidence and present it in court at the preliminary hearing. What was to be the role of the police? Pretty clearly it was intended that they should assume the burden of imvestigation. ${ }^{42}$ But were they to have the same powers that the magistrates had enjoyed in investigating suspected offenders? In particular, were they to be authorized to arrest persons and conduct in-custody investigations, including interrogation, to determine whether to bring such persons before the magistrate and charge them with offenses?

Unfortunately, the law never faced these questions squarely. The magistrate was deprived of powers, but little formal attention was given to determining which, if any, of these powers should be transferred to the police. Instead, the old laws governing the constable when he was a mere agent of the magistrate in the investigative process were applied to the police. They now bore the full responsibibty for securing the evidence that,

40 Mattiand, Justice and Poltce 100 (1885). For a more detailed account of the statutory development in England, see ALI Code or CrDminal Procedure 266-68 (1930). See also Orfield, Crmatuat Procedure From Arrest to Appeal 53-58 (1947).

41 For a detailed description indicating the extent to which the magistrate himself directed the investigation, see 1 CEMTTY, CrmunNaL LAW 72-89 (1826).

42 Devis 8; cf. Williams, Questioning by the Police: Some Further Points-2, [1960] CRNC. L. REv. (Eng.) 352, 353, in which the author states that the original intention was for the police to operate primarily as a preventive body with the justices retaining the investigative functions, but that this lasted only ten years, partly because the police establishect their own system of investigation, "largely on their own initiative." 
when presented to the magistrate, would justify holding the defendant for trial. ${ }^{43}$ In fact, both in this country and in England the theory of the law has continued to be that the primary responsibility for determining whether a person shall be taken into custody and whether he shall be held to answer for a public offense is vested in the magistrate. The typical statute begins by describing a hearing before the magistrate in which a complainant and witnesses are examined and a warrant of arrest issued if probable cause is found. The duty of the officer in executing the warrant is purely ministerial -he makes the arrest and brings the defendant before the magistrate for further proceedings. Arrests without warrants are recognized, but as exceptional proceedings: the duty of the officer is to take the defendant as promptly as possible before the magistrate where there can be a hearing to determine probable cause. ${ }^{44}$ The Supreme Court of the Umited States was doing no more than describing the law generally when it said in Mallory $v$. United States:

The scheme for initiating a federal prosecution is plainly defined. The police may not arrest upon mere suspicion but only on "probable cause." The next step in the proceeding is to arraign the arrested person before a judicial officer as quickly as possible so that he nuay be advised of his rights and so that the issue of probable cause nuay be promptly determined. ${ }^{45}$

The logical inference from these traditional rules is that "arrest, even on probable cause, is not properly a vehicle for the investigation of crime." 6

43 The extent to which English precedents antedating the shift of investigative powers from the justices to the police were rehed on to determine American law in the latter half of the 19th century can be seen by examining the footnotes in 1 Bishop, Cromanal ProCEDURE 91-143 (2d ed. 1872); see also Note, Some Proposals for Modernizing the Law of Arrest, 39 CALIF. L. REv. 96, 97 (1951). For the English development see Devrrs 1-30.

44 See generally ALI Code of Cromanal Procedure 21-40, 173-334 (1930); Ceislets, The Magistrates' Courts Act, Runes and Forms 9-36 (1953); Devinn 82; Hall, The Lave of Arrest in Relation to Contemporary Social Problems, 3 U. CHI. L. REv. 345 (1936); Remington, The Law Relating to "On the Street" Detention, Questioning and Frisking of Suspected Persons and Police Arrest Privileges in General, 51 J. CRno. L., C. \& P.S. 386 (1960); Warner, Modern Trends in the Law of Arrest, 21 CAN. B. REv. 192, 212 (1943). Of course, there has been some statutory modification here and there. For example, the California statutes from 1850 to 1951 required the magistrate, when a complaint was filed, to examine "the informant or prosecutor, and any witnesses he may produce," on oath and to issue a warrant of arrest only if he found probable cause from such examination. Cal. Stats. 1850 ch. 119, \$§ 105-107; Cal. Stats. 1851 ch. 29, § 106. In 1951 the statute was amended to limit the duty of the magistrate to examining the face of the complaint. CAL. PEN. CODE $\$ 813$.

45354 U.S. 449,454 (1957). For a case stressing the role of the magistrate in determining when an arrest warrant should issue, see Giordenello v. United States, 357 U.S. 480 (1958).

46 Hogan \& Snee, The McNabb-Mallory Rule: Its Rise, Rationale and Rescue, 47 GEo. L.J. 1, 23 (1958). Accord, Keefe v. Hart, 213 Mass. 476, 100 N.E. 558 (1913); Harness v. Steele, 159 Ind. 286, 64 N.E. 875 (1902); Bohlen \& Shulman, Effect of Subsequent Misconduct Upon a Lawful Arrest, 28 Colum. L. Rev. 841, 852 (1928). But cf. Orfieid, Crocunat Procedure FROAK ARREST to APPEAL 23-25 (1947); Scurlock, Arrest in Missouri, 29 U. Kan. CitY L. Rev. 117, 127-29 (1961). 


\section{As Professor Sherry put it:}

The police are without legal authority to hold a defendant in custody for the purpose of detaining him until an investigation is completed. The law contemplates that the defendant, upon arrest, will be taken before a magistrate "without unnecessary delay," that a formal complaint will be filed in the event the arrest has been without a warrant and that the defendant will be arraigned on the charge. ${ }^{47}$

This procedure might have worked with reasonable success in the simpler society of two centuries ago. It would bear some relation to reality even today in a society that put the main responsibility for initiating and carrying forward criminal proceedings upon the victim or his friends and provided adequate numbers of magistrates to screen the complaints. But that it has not worked in this country ${ }^{48}$ has long been clear. Citizens have gladly left to the police the principal responsibility for initiating criminal proceedings. Legislatures have created numerous crimes in which participation is consensual and there is no victim to complain. Laws against gambling, prostitution, sale and use of narcotics, and others throw full responsibility upon the police to discover the existence of the crime as well as the identity of the criminal. ${ }^{40}$ Furthermore, all aspects of the criminal investigation process are complicated by the increased mobility of our population. ${ }^{50}$ No longer can the policeman in our cities depend upon his knowledge of the inhabitants of the neighborhood as the prime means of investigation. The suspect is often a stranger, and even if known to the officer, there is no assurance that a few hours delay will not result in his disappearanceperhaps to a place of refuge a thousand miles distant. And finally, our cities have not provided anything approaching the number of magistrates necessary to the performance of the functions that the law has assigned them.

47 Sherry, The Law of Arrest, Search and Seizure 58 (Cal. Peace Off. Train. Pub. No. 1, 5th rev. 1957).

$48 \mathrm{It}$ is not within the scope of this article to examine the development of practices in England. However, it is worth noting that practices there apparently do not conform as closely to the model of the law as has been generally assumed. Professor Glanville Williams stated recently: "Even in England the police make a practice of 'detention for questioning', thougl they limit it at most to three or four days." Williams, Police Detention and Arrest Privileges, 51 J. Crtm. L., C. \& P. S. 413 (1960). See generally Devirin; Justice, Premininary Investigations of Crimmal Offenses (1960); Brownlie, Police Questioning, Custody and Caution, [1960] Cras. L. Rev. (Eng.) 298; Smith, Questioning by the Police: Some Further Points-1, [1960] Crnar. L. Rev. (Eng.) 347; Williams, Questioning by the Police: Somse Practical Considerations, [1960] CRIM. L. REv. (Eng.) 325; Williams, Questioning by the Police: Some Further Points-2, [1960] CRar. L. REv. (Eng.) 352. See also Culombe v. Connecticut, 367 U.S. 568, 593-98 (1961); Barrett, Personal Rights, Property Rights, and the Fourth Amendment, 1960 Sur. Cr. REv. 46, 66-68.

49 See Allen, Federalism and the Fourth Amendment: A Requiem for Wolf, 1961 Sup. CT. REv. 1, 38-39.

50 See Santh, Poutce Systexs In the UntTed States 48 (2d rev. ed. 1960); Rotenberg, Extraterrilorial Legislative Jurisdiction and the State Criminal Law, 38 TExAs L. Rev. 763, 765 (1960). 
A city that has thousands of policemen making hundreds of thousands of arrests each year may provide less than half a dozen judges who are assigned to the task of conducting preliminary hearings. ${ }^{51}$ Hence, as Professor Warner pointed out two decades ago, police and prosecutors have taken over the investigative and screening functions; it is "not that they are endeavoring to usurp the power of the magistrates, but that there are not enough magistrates to do this work.".52

Generalizations about police practices in this country are apt to be highly misleading because of the wide variations that exist-even within a single state, as will be shown in the next section of this paper. Still it is probably safe to assume that in several respects the procedures in cities throughout the country are similar. The decision whether to take a suspect into custody is almost always made by the police and prosecutors rather than the magistrate. Arrests with warrants are the exception, and even when they are used, the magistrate often merely ratifies a decision reached by the police or the prosecutor. Much police investigation, including interrogation, takes place after suspects have been taken into custody. And in a high percentage of cases (though here variations in practice may be wider) the decision whether the arrested person should go free or be held for trial is made in fact, if not in form, at the police-prosecutor rather than the magistrate level. ${ }^{53}$

51 Compare Nutter, The Quality of Justice in Misdemeanor Arraignment Courts, 36 Los ANGeres B. BUL. 338 (1961), describing the limited amount of judicial time available at the later (and obviously more vital) stage where the defendant pleads and in most cases ( $80 \%$ plead guilty in the Los Angeles arraignment courts) is sentenced.

02 Warner, Modern Trends in the American Law of Arrest, 21 Cav. B. Rev. 192, 212 (1943).

53 Factual data to substantiate the conclusions stated in this paragraph are almost nonexistent. See Foote, Safeguards in the Lav of Arrest, 52 Nw. U.L. Rev. 16, 20 (1957): "Factual assumptions made about police arrest practices today necessarily rest upon pohitical philosophy or armchair speculation, seasoned with scattered and unreliable statistics, isolated studies, personal experiences, or undocumented police claims." There is general agreement, however, that in these areas there is a wide gulf between the law and the practices of the police. See, e.g., Culombe v. Connecticut, 367 U.S. 568, 572-73 (1961) ; BartH, The Price of LibertY

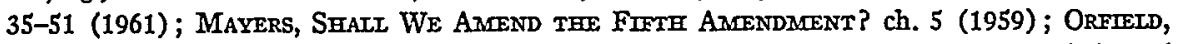
Crnamanal Procedure frome Arrest to Appeal 5, 23, 35 (1947); Hearings on Admission of Evidence (Mallory Rule) Before a Subcommittee of the Senate Committee on the Judiciary, 85th Cong., 2d Sess. (1958); Hearings on Confessions and Police Detention Before the Subcommittee on Constitutional Rights of the Senate Committee on the Judiciary, 85th Cong., 2d Sess. (1958); Hearings on Mallory ws. United States Before the Special Subcommittee to Study Decisions of the Supreme Contrt of the United States of the House Committee on the Judiciary, 85th Cong., 2d Sess., ser. 12, pt. 1 (1958); Hogan \& Snee, The McNabb-Mallory Rule: Its Rise, Rationale and Rescue, 47 Geo. L.J. 1, 22-24 (1958); Paulsen, The Fourteenth Amendment and the Third Degree, 6 StaN. L. Rev. 411 (1954); Warner, Investigating the Law of Arrest, 26 A.B.A.J. 151 (1940); Note, Some Proposals for Modernizing the Law of Arrest, 39 CarIF. L. Rev. 96, 100 (1951); Note, Philadelphic Police Practice and the Law of Arrest, 100 U. PA. L. Rev. 1182 (1952). Data compiled by the American Bar Foundation study of the Administration of Criminal Justice in the United States that was made available to the author for examination also provides general substantiation for the statements in the text insofar as the jurisdictions surveyed in that study are concerned. 
This deviation from the law has long been recognized by the courts in the cases involving confessions obtained by post-arrest interrogation. Only last year Justices Frankfurter and Stewart in their opinion in Culombe v. Connecticut, ${ }^{54}$ after referring to the arguinent made "in quarters responsible and not unfeeling" that without police interrogation of suspects in custody "it is often impossibile to close the hiatus between suspicion and proof," noted that courts in this country have not excluded all confessions obtained from suspects in custody.

Rather, this court (in cases coming here from the lower federal courts) ... and the courts of all the States have agreed in holding permissible the receipt of confessions secured by the questioning of suspects in custody by crime-detection officials. And, in a long series of cases, this Court has held the Fourteenth Amendment does not prohibit a State from such detention and examination of a suspect as, under all the circumstances, is found not to be coercive. ${ }^{55}$

In most instances the courts have not even discussed whether in-custody investigation by the police is legal, concentrating instead on determining the point at which the police have gone too far in their interrogation practices so that the confession should be regarded as coerced. ${ }^{56}$ In the few cases where the issue of illegality has been pressed, most state courts have refused to follow the federal courts in excluding evidence obtained during periods of illegal delay and hence have not needed to mark out the boundaries of proper police conduct short of that extreme characterized as coercion. ${ }^{57}$ More recently, however, judicial sensitivity to the argument that police illegality should not be condoned has resulted in an occasional decision re-interpreting the governing law so as to make permissible the kind of in-custody investigation by police that the court regards as practically necessary. ${ }^{58}$

Legislatures, too, have recognized, although usually only by inference rather than direct stateinent, that police do hold people in custody for pur-

54367 U.S. 568, 587 (1961). This opinion should be consulted for its full discussion of the police interrogation problem and for the exhaustive hibliography contained in its notes.

55 Id. at 589-91. (Footnotes omitted.) Cases from every jurisdiction are cited in the footnotes to this portion of the opinion.

56 See generally Maguire, Evidence of Guilt ch. 3 (1959); McCormick, Evidence ch. 12 (1954).

57 For the federal rule, see Mallory v. United States, 354 U.S. 449 (1957). The reaction of the states to this rule is summarized in Culombe v. Connecticut, 367 U.S. 568, 600 n.53 (1961). See also MagutRe, Evidence of GuIIt ch. 4 (1959); Rothblatt \& Rothblatt, Police Interrogation: The Right to Coutsel and to Prompt Arraignment, 27 BRoorLYN L. Rev. 24 (1960); Annot., 19 A.L.R.2d 1331 (1951). For recent treatment of the problem in California, see People v. Garner, 57 A.C. 151, 367 P.2d 680, 18 Cal. Rtpr. 40 (1961) ; People v. Kendrick, 56 A.C. 59, 363 P.2d 13, 14 Cal. Rptr. 13 (1961).

58 See State v. Smith, 32 N.J. 501, 534, 161 A.2d 520, 537 (1960), cert. denied, 364 U.S. 
poses of investigation. Statutes commonly provide for access to counsel at the police station and for telephone calls or other methods of communication with persons on the outside. ${ }^{59}$ An occasional statute recognizes the authority of police to arrest persons on suspicion and hold them in custody for defined periods of investigation. ${ }^{60} \mathrm{~A}$ few states have adopted the pro-

936 (1961):

Speaking generally, talking to people and asking them questions, whether they be suspects or not, is a standard and most essential element of crime solution and law enforcement. While police brawn and bluster to extort confessions cannot be a substitute for brains and leg work and will not be countenanced, the public interest requires that interrogation, and that at a police station, not completely be forbidden, so long as it is conducted fairly, reasonably, within proper limits and with full regard to the rights of those being questioned. This right in the authorities bas always been assumed in this State, even when the purpose may bave been to attempt to obtain an admission of guilt, and the assumption tacitly runs through all of our decisions dealing with questions of admissibility of confessions claimed to have been coerced during such a process.

In a subsequent habeas corpus proceeding brought by the defendants in the Smith case, the federal district court demied relief, saying inter alia:

Unduly continued detention with extensive and persistent questioning may amount to such psychological pressure as to destroy the voluntary character of statements made under such conditions. This does not mean, however, that police officers may not question suspects in an attempt to discover the truth about the existence or commission of a crime. In fact in many instances immediate interrogation is higlly advisable. It is only when fundamental unfairness results from undue extension of the time of examination so as to constitute it a veritable "third degree" that such confessions and statements are to be refused admission into evidence.

United States ex rel. Simith v. New Jersey, 194 F. Supp. 691, 693 (DN.J. 1961).

For a recent federal attempt to sustain police questioning in custody as being consistent with the McNabb-Mallory rule, see United States v. Vita, 294 F.2d 524, 533 (2d Cir. 1961):

If the purpose is investigatory, and not simply to keep the accused in custody until he confesses, if the police bave good reason to believe that the suspect must be questioned further in order to determine whether he or any other person ought to be arrested, detention for a reasonable period of time is permissible and any confession obtained during it is admissible. . . . So long as the Federal Rules of Criminal Procedure do not designate any period of time during which the police may question a person whom they have reason to suspect of a crime, investigatory interrogation under adequate safegnards should be permitted before the accused is taken to a committing nuagistrate.

See also Umited States v. Ladson, 294 F.2d 535 (2d Cir. 1961) ; People v. Garner, 57 A.C. 151, 367 P.2d 680, 18 Cal. Rptr. 40 (1961); Note, 1960 WIs. L. Rev. 164 (discussing Wisconsim cases approving in-custody investigation).

50 See e.g., Alaska Coxrp. Laws Anv. 66-5-34 (1949); Cad. Pen. Code §§ 825, 851.5; Iowa Laws ch. 373 (1959); LA. Rev. Stat. § 15:77 (Supp. 1961); Mass. GeN. Laws ANN. ch. 276, § 33A (Supp. 1961) ; Mo. Rev. Stat. \$ 544.170 (Supp. 1961); N.H. Rev. Stat. ANN. § 594:15-17 (Supp. 1961); N.C. GeN. StaT. \$15-47 (Supp. 1959); OHIo Rev. Code ANN. \$ 2935.16 (Page 1958); TeX. PEN. Code art. 1176 (Supp. 1961).

60 See Hawan REv. Laws $\$ \$ 255-4,255-5,255-9$ (1955). A less explicit provision is found in Mo. Sup. CT. R. 21.14, discussed in Scurlock, Arrest in Missouri, 29 U. Kan. CITY L. Rev. $117,127-29$ (1961). 
visions of the Uniform Arrest Act authorizing police to detain persons for short periods of questioning im order to determine whether a fornial arrest should be made. ${ }^{61}$ Recently, California has fornially recognized the role of the police in determining whether or not an arrested person shall be cliarged and held for trial by providing that a peace officer "may release from custody, instead of taking such person before a magistrate, any person arrested without a warrant whenever: (1) He is satisfied that there is no ground for making a criminal conplaint against the person arrested. ... .'B2

But neither courts nor legislatures have faced up to the problem in all its complexities. What powers should police have to conduct investigations prior to taking the step of arresting the defendant? Under what circumnstances should police be permitted to talke persons into custody for the purposes of investigation? What should be the limitations upon the duration and nature of such in-custody investigation? What is the most appropriate method for insuring compliance by the police with the rules? These and similar questions have yet to be answered in any organized fashion that takes existing conditions into account..$^{68}$ The resulting situation is rapidly becoming intolerable. On the one hand police are being subjected to ever-increasing criticisin for conduct that is regarded by many, including the judges of distinguished courts, as the perfornance of "a definite obligation of the highest order to the public ...." On the other hand, the police are left with so little in the way of definitive and realistic rules gov. erning the specifics of their operations (and of practical controls to see that they abide by the rules) that the danger of abuse is always present.

What is needed, and needed now, is a careful examination of these complex probleuns in order to determine the most appropriate pattern for legis. lative reforn. The last sections of this article contain an analysis of the degree of correlation between police practices and the controlling law in California. Although the available data is obviously inadequate to support definite conclusions, sonve suggestions are offered concerning the types of legislative regulations that should be considered in the search for solutions.

61 Des. Code AnN. tit. 11, $\S 1902$ (Supp. 1960); N.H. Rev. Stat. ANN. 8594.2 (Supp. 1961) ; R.I. GEN. LAws ANN §§ 12-7-1, 12-7-13 (Supp. 1960). The act is set out and discussed in Warner, The Uniform Arrest Act, 28 VA. L. REv. 315 (1942). See also Remington, supra note 44.

${ }^{62} \mathrm{CAL}$. PEN. CODE $\$ 849$, as amended in 1957 . Somewhat similar provisions will be found, as part of the Uniform Arrest Act, in DEL. CODE ANN. tit. 11, $\$ 1910$ (Supp. 1960); N.H. REv. Stat. AnN. $\$ 594.18$ (Supp. 1961); R.I. Gen. Laws ANN. \$ 12-7-12 (Supp. 1960).

63 For a careful discussion of the deficiencies of the law in this area see Remington, supra note 44 . For a 1961 attempt to deal with many of these problems in the juvenile context, see CAI. Welfare \& INST'NS CODE $\$ \$ 625-32$, set out in part in note 120 infra. For an English pohice plea for clarification of the law in this area, see Helping the Police, 69 Pource REv. (Eng.) 18 (1961).

64 State v. Smith, 32 N.J. 501, 530, 161 A.2d 520, 535 (1960). 
THE LAW AND THE PRACTICE-SOME DATA FROM CALTFORNIA

Very little reliable information is available concerning the actual practices of law enforcement agencies. ${ }^{65}$ Police departments collect and analyze large amounts of statistical data. Understandably, however, they collect such data for purposes useful to them in the day-to-day work of law enforcement. Given the usually severe limitations of budget and manpower, they cannot be expected to collect data useful primarily to outsiders who are interested in understanding, analyzing, and evaluatmg the law enforcement process. Much of the relevant information is in fact contaimed within police files, needing only the application of money and inanpower to cull it out and analyze it.

This writer has attempted over the past three or four years to ascertain what information can be obtained about police practices in California without going to the time and expense of a full-scale, scientifically-based survey. Published literature has been examined. Statistical data published by police departments in Califorma and by the Califorma Bureau of Criminal Statistics have been analyzed. A highly impressionistic survey of actual practices has been made by visits to a limited number of police departments in California and by discussions with police, prosecutors, defense counsel, and judges. Two California police departments collected data over a short period (three months in each case) and made it available to the author for analysis.

The material that follows has been derived from this admittedly unscientific survey. ${ }^{66}$ It is presented not as a definitive statement of actual practices, but rather as a fairly reliable indication of how wide the divergence is between the law in the books and the law in practice. Also, it is hoped that it will suggest the areas in which studies of greater validity might usefully be made.

It is important to add at the outset one other note of caution against unwarranted generalizations from the material that follows. In few areas does practice vary so widely from locality to locality as in law enforcement. Even within a single state, practices in individual police departments, particularly in different counties, may vary tremendously even thougl the cities face similar problems and are located close to each other. Local autonomy necessarily results in practice variations.

${ }^{65}$ See Beattie, Criminal Statistics in the United States-1960, 51 J. CRAr. I., C. \& P.S. 49 (1960); Foote, Safeguards in the Law of Arrest, 52 Nw. U.L. REv. 16 (1957).

00 This study is limited to adult felony arrests, the only ones for which extensive statistical data are available. 


\section{A. Screening in Felony Cases in California}

California has relatively complete statistics on arrests and dispositions in adult felony cases. The Bureau of Criminal Statistics of the California Department of Justice collects statistics from all police and sheriffs' offices and from all district attorneys. In addition, it utilizes field personnel and constant supervision in an attempt to maintain accurate reporting. The results are compiled annually in a publication called Crime in California. Unless otherwise noted, the statistics presented in this section cover the calendar year 1960 and are taken from Crime in California 1960. ${ }^{\circ 7}$

To understand the system and its problems it is necessary to look at the total process-from the police decision to arrest to the determination of court or jury after a case has gone to trial. It is also necessary to examine the variations, both by geographical area and by offense grouping, that illuminate the process and give some insight into why it works as it does.

\section{The Arrest Decision}

The decision whether or not to make an arrest is made in different ways and at different levels in the process. In a relatively small number of cases a complaint is filed with the magistrate (either because of a formal complaint from a citizen or as the result of prior police investigation) and a warrant issued directing the arrest of the defendant. In a few cases indictments are secured from grand juries and warrants issued thereon to effect the arrests. Unfortunately, there are no statistics indicating the proportion of arrests in felony cases that are made on warrants. What evidence there is suggests that the proportion is very small, and that use of warrants is confined mainly to a few types of offenses. ${ }^{08}$

The normal procedure, which undoubtedly accounts for most felony arrests, is for the policeman to decide for himself whether or not to make an arrest under the particular circumstances. If he decides not to make an arrest, the decision is neither visible, nor $\mathrm{m}$ the main, reviewable. ${ }^{09} \mathrm{How}$ he makes the decision is, of course, an amalgam of many factors-his own

g7 State of Calte, Bureat of Crommat Statistics, Dep't of Justice, Crome in California 1960 [hereinafter cited as CrIME IN CaltFornia 1960]. For a description of some of the problems in gathering the data, see Beattie, suibra note 65, at 58-60; StaTe or Carte., Bureau of Crimmal Statistics, Dep't of Justice, Narcotic Arrests and Their Dispositions IN CALIFornIA, January 1, 1960-December 31, 1960, pp. 1-6 [hereinafer cited as CAL. NARCOTIC ARRESTS 1960]. A 1961 California statute requiring full reporting of the disposition of cases by law enforcement agencies and courts should materially increase the reliability of the California data. CAI. Pen. Code \$§ 11115-17; see CaI. Narcotic ARrests 1960, at 4.

68 See CrIME IN CAIIFORNIA 1960, at 67; "Forgery and check offense arrests and arrests for sex offenses are made in a large number of instances as the result of complaints having been signed and arrest warrants issued."

69 See Goldstein, Police Discretion Not to Invoke the Criminal Process: Low-Visibility Decisions in the Administration of Justice, 69 YALE L.J. 543 (1960). 
personality and prejudices, his knowledge of police department policy, his knowledge of the types of cases in which the prosecuting officer will issue a complaint, his knowledge of judicial decisions as they bear on the situation.

It should be noted here that we have no statistical or other evidence of significance that tells either (1) how often the police do not make arrests when they are legally empowered (and perhaps obligated) ${ }^{70}$ to do so, or (2) how many of the arrests actually made by police were made without lawful authority. Short of hitigating the issue in each arrest, there is no way to know whether the officer acted legally, i.e., had "reasonable cause to believe that the person to be arrested has committed a felony." ${ }^{11}$ Certainly it is not relevant that the person was booked "for investigation of" or "on suspicion of" a particular crime. ${ }^{72}$ The booking charge (generally a police record not even required by the law) tells nothing about whether the officer had "reasonable cause" when he made the arrest. The situation would not be changed, legally or factually, if the police as a matter of practice booked all arrested persons "on the nose" instead of starting with the more qualified charge. ${ }^{73}$ Nor does the release of a substantial number of arrested persons without the filing of a complaint against them indicate that the arrests

70 See Lees v. Colgan, 120 Cal. 262, 52 Pac. 504 (1898); People v. Mullin, 197 A.C.A. 508, 17 Cal. Rptr. 516 (1961); CaL. Gov'T Code $\$ \$ 26601-02$; Cax. Pen. Code $\$ \S 142,335$; Note, Some Proposals for Modernizing the Law of Arrest, 39 CaLrF. L. REv. 96, 103 (1951). It should be noted, however, that in tort suits brought against police officers for failure to make arrests, the courts have refused recoveries by emphasizing the discretionary character of the arrest decision. See Tomlinson v. Pierce, 178 Cal. App. 2d 112, 2 Cal. Rptr. 700 (1960); Rubinow v. County of San Bernardino, 169 Cal. App. 2d 67, 336 P.2d 968 (1959).

71 CAL. PEN. CODE $\$ 836$.

72 But cf. Barth, THe PrICE of LiberTy 42-45 (1961); Foote, Safeguards in the Law of Arrest, 52 Nw. UL. Rev. 16, 20-27 (1957).

73 One California district attorney recently described the practice and the reasons for it as follows:

You are all probably sounewhat concerned with an expression which is used when a person is arrested for a felony, called "he is arrested on suspicion of a felony."

In the minds of some people this has a connotation that we merely suspect that the person has coinmitted a crime and, therefore, we arrest him so that we could give him the third degree and all of the other things which are sometimes referred to by our appellate courts, in order to prove that he has committed a crime. This is not so.

It may be unfortunate in one light that the word "suspicion" is used. The reason it is used is because it is a universal term and it is understood in law enforcement circles, wherever it is used. Let ine say this to you, though:

The only arrest which is a proper arrest is an arrest made upon reasonable cause or upon a warrant. The inan who is arrested and booked upon suspicion is a man who has been arrested where there has been reasonable cause to make the arrest.

In the old days the officer would book him as, we say, "straight."

Let us assume that a man is booked on suspicion of robbery. In the old days that arrest would have been an arrest for robbery. The reason we arrest him on 
were necessarily illegal. ${ }^{74}$ As will be discussed below, the release decision will often be made on grounds that cast no doubt on the legality of the arrest itself. We know that some undisclosed percentage of police arrests for felony are made unlawfully. But we do not know, nor do we have any satisfactory way of finding out, whether that percentage is large or small.

\section{The Charge Decision}

In discussing the law and practice relating to the period between arrest and the filing of a formal complaint with the magistrate, several issues must be treated separately. What is the relationship between the standard that governs the decision to arrest and the standard that governs the decision of the magistrate to hold the defendant to answer? ${ }^{75}$ Subsequent to arrest and prior to charging, may the police lawfully conduct an investigation to determine whether there is evidence in addition to that available at the time of arrest to support the charge? If so, what are the limitations upon the conduct and duration of such an investigation? Does the law authorize the police to release the defendant without taking him before a magistrate when investigation shows that there is insufficient evidence to justify the magistrate in holding him to answer?

Despite verbal differences in the governing statutes, ${ }^{76}$ the California

suspicion or have him on suspicion is that that is not a complete booking. Before that booking can be changed, the District Attorney must look at the case.

The District Attorney looks at the case and makes a determination as to what the charge shall be and, until that time, it is only suspicion.

Now, if the District Attorney decides that the booking shall be robbery, it goes through the usual process. The man has a record of having been arrested for robbery.

If the District Attorney decides that he shall be turned loose or perhaps booked on some lesser charge, then the only mark against him is on the record that he was arrested originally on suspicion of having committed a crime.

Now, you know as well as I do, if you look at a criminal record and you see that a man was arrested for robbery, and the District Attorney dismissed the case, there immediately arises in the minds of many people the thought well, they had him for robbery, he got dismissed, he put in the fix or something of that order. ...

But today in California on such an arrest, if you are turned loose by the District Attorney, a notation is made upon the record to that effect, that this is not an arrest but is merely a detention under appropriate sections of the Code.

Lynch, A District Attorney Looks at the Criminal Case, in Crommar Law Semmar 51, 55-56 (Cohn ed. 1961). But cf. United States v. Killough, 193 F. Supp. 905, 910 (D.D.C. 1961) (dictum that even where probable cause exists, a booking charge of "suspicion" is illegal and hence the custody is illegal).

74 But cf. authorities cited note 72 supra.

75 See generaily, Remington, supra note 44, at 393.

76 Under CAI. PEN. CODE $\$ 836$ a peace officer may make an arrest without a warrant "whenever he has reasonable cause to believe that the person to be arrested has committed a felony, whether or not a felony has in fact been committed." Under CAx. PEN. CodE $\$ 872$ 
courts state the same standard for the arrest decision as for the decision to hold to answer. The California Supreme Court recently stated that the reasonable cause justifying an arrest without a warrant "has been generally defined to be such a state of facts as would lead a man of ordinary care and prudence to believe and conscientiously entertain an honest and strong suspicion that the person is guilty of a crime. ... The test is not whether the evidence upon which the officer acts in making the arrest is sufficient to convict but only whether the person should stand trial." "In another recent case the court stated that

The evidence before a committing magistrate at a preliminary examination need not be such as would require a conviction. The "sufficient cause" required by section 872 means merely that there is a reasonable or probable cause for believing that defendant is guilty of the crime charged. "Reasonable or probable cause" neans such a state of facts as would lead a man of ordinary caution or prudence to believe and conscientiously entertain a strong suspicion of the accused's guilt. ${ }^{78}$

Despite the language in these cases, it should not be assumed that a person can be arrested only when the evidence available, if presented to the magistrate, would be sufficient to justify him holding the defendant to answer. The policeman determines probable cause to arrest upon the basis of the facts known to him at the time of arrest. The magistrate determines probable cause to hold the defendant to answer upon the basis of the facts presented to him in the court-at a later point in time and in a quite different context.

The Califorma law does not directly answer the question whether police investigation after arrest and prior to charging is legitimate and, hence, it does not directly regulate the conduct of such investigation. Only the time interval between the arrest and the appearance before the magistrate is regulated. The statute requires that the defendant must be brought before the magistrate "without unnecessary delay, and, in any event, within two days after his arrest, excluding Sundays and lolidays; provided, however, that when the two days prescribed herein expire at a time when the court in which the magistrate is sitting is not in session, such time shall be extended to include the duration of the next regular court session on the

the magistrate may hold the defendant to answer if "it appears from the examination that a public offense has been committed, and there is sufficient cause to believe the defendant guilty thereof. ...."

77 People v. Ingle, 53 Cal. 2d 407, 412-13, 348 P.2d 577, 580, 2 Cal. Rptr. 14, 17 (1960). As one of the authorities for determining the meaning of probable cause to arrest, the court cited People v. Nagle, 25 Cal. 2d 216, 153 P.2d 344 (1944), a leading case on probable cause necessary to justify a magistrate in holding the defendant to answer.

78 Robinson v. Superior Court, 49 Cal. 2d 186, 188, 316 P.2d 1, 2-3 (1957). 
judicial day immediately following." ${ }^{39}$ Cases have not dealt explicitly with the question whether delay for the purposes of investigation is necessary delay within the meaning of this statute, ${ }^{80}$ nor does the question often arise since California does not follow the $M c N a b b-M a l l o r y$ exclusionary rule. ${ }^{81}$

Only on the question of release after investigation is the California law clear. A 1957 statutory amendment explicitly authorizes a peace officer to "release from custody, instead of taking sucli person before a magistrate, any person arrested without a warrant whenever: (1) He is satisfied that there is no ground for making a criminal complaint against the person arrested. Any record of sucli arrest shall include a record of the release hereunder and thereafter shall not be deemed an arrest but a detention only. ..."82 This statutory provision could reasonably be interpreted as legislative recognition of the legitimacy of police investigation after arrest as well as of the legitimacy of police releases. However, no case has been found dealing with the issue.

The practice in California, unlike most aspects of the governing law, is reasonably ascertainable. Police do conduct investigations after arrest for the purpose of determining whether to release or to charge the defendant. The decision to charge is regarded as a far more serious decision than the decision to arrest-in fact it is usually thought of as calling for admissible evidence showing a high probability of guilt. ${ }^{83}$ As a result, a very substan-

${ }^{70}$ CAL. PEN. CODE $\$ 825$. This statute is located in the chapter of the code dealing with arrests on warrants. Section 849 , which deals explicitly with arrests without warrant, merely provides a standard of "without unnecessary delay." However, it seems settled that $\S 825$ is the governing statute for all arrests, with or without warrant. See People v. Kendrick, 56 A.C. 59, 70, 363 P.2d 13, 18, 14 Cal. Rptr. 13, 18 (1961); Dragna v. White, 45 Cal. 2d $469,472-73,289$ P.2d 428, 430-31 (1955). This conclusion is remforced by the fact that the legislature in 1961 added to $\$ 825$ the portion quoted above after the word "provided," but did not amend § 836 .

80 The question whether the delay was "unnecessary" has arisen in a few suits for false imprisonment. In these cases, lowever, the courts have not articulated the standards to be used in determining whether delay is necessary. See, e.g., Dragna v. White, supra note 79; Lincohı v. Grazer, 163 Cal. App. 2d 758, 329 P.2d 928 (1958). In both of these cases the question arose on demurrer. In several cases it has been held that whether delay is "unnecessary" is a question of fact to be determined by the court or jury. Oguhin v. Jeffries, $121 \mathrm{Cal}$. App. 2d 211, 263 P.2d 75 (1953); Kaufman v. Brown, 93 Cal. App. 2d 508, 209 P.2d 156 (1949).

81 People v. Garner, 57 A.C. 151, 367 P.2d 680, 18 Cal. Rptr. 40 (1961); Pcople v. Kendrick, 56 A.C. 59, 363 P.2d 13, 14 Cal. Rptr. 13 (1961); Rogers v. Superior Court, 46 Cal. 2d 3, 291 P.2d 929 (1955). In a few cases dealing with the issue of coerced confessions the courts have indicated disapproval of obviously unjustified periods of delay. See, e.g., People v. Stroble, 36 Cal. 2d 615, 226 P.2d 330 (1951) ; People v. Grace, 166 Cal. App. 2d 68, 78-79, 332 P.2d 811, 817-18 (1958) ; People v. Speaks, 156 Cal. App. 2d 25, 319 P.2d 709 (1957). In other cases the courts have merely noted the facts concerning the delay without expressing approval or disapproval. See, e.g., People v. Garner, supra; People v. Kendrick, supra; People v. Atchley, 53 Cal. 2d 160, 346 P.2d 764 (1959).

82 Cad. Pen. Code $\S 849$.

${ }^{83}$ See Metropolitan News (Los Angeles), Jan. 5, 1962, p. 1, where Mr. Roger Arnebergh, 
tail part of the screening process is accomplished at the police-prosecutor level. In fact, more than twice as many people are released after felony arrests without the filing of formal charges (either felony or misdemeanor charges) as are screened out in the entire process of preliminary hearing, grand jury proceedings, and trial.

The general outlines of the practice are made visible by the full statistics published annually in Crime in California. However, some general caveats should be expressed. The statistics do not tell the extent to which the release decision is made by the police and the extent to which it is made by the prosecutor. The prosecutor's decision may be expressed either formally, through demal of a requested complaint, or informally, through welldefined office policies delimiting the circumstances under which a complaint will be authorized. The relative weight of pohice and prosecutors in the decision will vary from place to place and from time to time, depending in the main on the people occupying the strategic positions in the two offices at the time in question. ${ }^{84}$ Nor, of course, do the statistics tell the extent to which the release decision, whether made by police or prosecutor, is determined by known policies of the courts. For example, no statistics tell how often an arrested person is released because the police or the prosecutors know that the rules applied by the courts will result in the exclusion of the only substantial evidence available against the accused.

It should also be noted that the statistics do not show the entire picture because they do not show all arrests. An arrested person does not become a statistic until he is booked and an arrest report filed. A policeman may make an arrest and release the arrested person without booking hin or filing an arrest report. A policeman may be called because of a shooting in a bar. He may compel everyone present to remain until he has had a chance to look around and talk to people. After a brief period he may release the persons held and no arrests would be recorded. Or the officer may stop a car in suspicious circumstances, question the driver, then release him after receiving satisfactory answers. Thousands of field interrogations are con-

City Attorney of Los Angeles, in a letter to the Mayor of Los Angeles, makes the following statements:

In this connection, I wish to advise that it is not the policy of this office to continue with the prosecution of any case, regardless of the offense charged, when in the opinion of the deputy charged with the responsibility for such prosecution the defendant is not guilty of such charge, or where we do not have available sufficient evidence to prove guilt beyond a reasonable doubt.

We will not be a party to convicting an innocent person; nor will we make a farce of a trial, harass a defendant, or impose upon the time of the court, by continuing with the prosecution of a case when we know in advance that the evidence available to us is insufficient to sustain a conviction. . . .

81 See Crame dn CaIffornia 1960, at 70; Lynch, supra note 73, at 54-57. 
ducted by police without being reported as arrests. Doubtless in many of these situations arrests will have been made within the ineaning of the statute providing that an arrest "is made by an actual restraint of the person. ..." ${ }^{185}$ Again, though we have no statistics, it is probably fair to assume that a substantial amount of screening takes place in this way.

In large metropolitan police departments there may be an even more formalized pre-booking screening procedure. For example, in one large California police department the normal daytime procedure is somewhat as follows: If an officer in a patrol car makes an arrest of a person suspected of robbery, he transports the arrested person (and the complaining witness if available) to the police station and takes hiln to a detective in the robbery squad office. After interviewing the officer, the arrested person, and any witnesses available, the detective signs an "arrest recommendation" slip, recommending either that the suspect be released or booked. Yet only in the event of booking is the suspect counted as an arrest for statistical purposes.

Once arrested persons are booked, however, the process becomes visible and quite reliable statistics are available concerning the place where the screening takes place. For calendar year 1960 police and sheriff's offices reported 98,821 adult felony arrests. ${ }^{86}$ What resulted from these arrests?

28,142 (28.5 per cent) of all those arrested were released by the police without the filing of any charge in court. ${ }^{87}$ There were wide variations in the release rate in different geographical areas of the state. In general, the

85 CAL. PEN. CODE $\$ 835$. For a discussion of the uncertain state of the law as to just what police conduct amounts to an arrest, see SherRY \& ColinNGs, The LaW of Arrest, Search ANd Seizure 2, 3, 37-40 (Cal Peace Off. Train. Pub. No. 1, 6th rev. 1961).

86 CrIME IN CaIrforna 1960, at 49. The figure given in the text is number of arrestrnot number of persons arrested. To complete the picture it should be noted that there were 555,333 adult misdemeanor arrests, id. at 48 ; and 74,889 arrests of juveniles for law violations, id. at 142.

87 CRDME IN CALIFORNIA 1960, at 68. The statement in the text is not precisely accurate since the data is collected on the basis of calendar-year occurrence, i.e., all releases during the year are recorded without reference to when the arrests occurred. This same limitation applies to all of the arrest and disposition statistics presented infra. For a more sophisticated series of statistical data in which the actual disposition of each arrest is counted even though that disposition took place after the end of the calendar year, sce Car. Narcorrc ArRests 1960. The distinction between the data in the narcotics report and those in CRnse IN CAIrrornin 1960 is discussed in the narcotics report at page 6. The narcoties report, wbich includes both felony and misdemeanor arrests and dispositions, shows "that of the 16,856 adult dispositions, a total of 6,940 , or 41.2 percent terminated in release, dismissal or acquittal; in 2,215 or 13.1 percent the narcotic charge was dropped in favor of other actions; and in 7,701 or 45.7 percent the arrest resulted in conviction of a narcotic charge-not necessarily the one for which the arrest was originally made. Of the convictions, 4,580 occurred in lower court and 3,121 in superior court." CaI. NARCotics ARrests 1960, at 29. This report does not distinguish between police releases and court dismissals or acquittals because of incompleteness of the data about the level of such dispositions. Id. at 4,32 . 
rate was highest in metropolitan areas and lowest in rural areas. ${ }^{88}$ Los Angeles County showed a release rate of 33.6 per cent, San Francisco of 33.8 per cent. On the other land, the more rural Sacramento Valley counties showed a rate of 10.6 per cent and the 22 least urban counties of only 7.2 per cent. ${ }^{80}$ There were also wide variations according to the type of offense. The highest release rates statewide were robbery, 42.6 per cent; aggravated assault, 32.2 per cent; burglary, 32.5 per cent; narcotics, 32 per cent. The lowest release rates statewide were forgery and checks, 10.3 per cent, and sex offenses, 17.9 per cent..$^{90}$

6,500 (6.6 per cent) of those arrested were turned over to other jurisdictions for prosecution. ${ }^{91}$

In 21,352 cases (21.6 per cent) the charge was reduced and a misdemeanor complaint filed. ${ }^{92}$ Here again there are geographical variations that closely approximate those in the figures on release without prosecution. In Los Angeles County misdemeanor complaints were filed against 25.3 per cent of those arrested on felony charges, while in the ten Sacramento Valley counties the rate was 9.6 per cent and in the 22 least urban counties, 10.4 per cent. ${ }^{93}$ These statistics reflect the extent to which screening by police and prosecutors resulted in decisions to file lesser charges even thougl the original police judgments, reflected in the arrest reports and booking charges, were that the defendants had probably committed felonies. No data are available about the disposition of these cases in the inunicipal courts. However, it is probably fair to assume that overall the conviction rate is very higl.

Relatively little screening takes place after the conplaint is filed with the magistrate. Police and sheriffs reported that 42,827 felony complaints were filed during $1960 .^{94}$ Figures submitted by prosecutors showed only 3,620 dismissals in the lower courts for reasons that would result in the release of the defendant. ${ }^{95}$ In 2,907 other cases the charge was reduced to a misdemeanor..$^{96}$ In summary, then, the figures show that of the 98,821 felony arrests, only 3.6 per cent were formally screened out by dismissals at the lower court levels while 28.5 per cent were released by the police.

88 See Crante in California 1960, at 67.

80 Id. at 69 , table IV-2.

90 Id. at 68 , table IV-1.

91 Id. at 69 , table IV-2.

32 Ibid.

83 Ibid.

94 Id. at 71 , table IV-3. For a discussion of the possible margin of error in this figure, see id. at 75 .

85 633 because victim unavailable or declines to prosecute; 2,987 for insufficient evidence or miscellaneous.

98 Crinte in Caltrornia 1960, at 78, table V-2. 
Similarly, of the arrests where the charge was reduced to misdemeanor, 21.6 per cent were reduced prior to filing and only 2.9 per cent by action of the court after filing.

During the 1960 calendar year this whole process resulted in felony charges being filed on 30,332 defendants in the superior courts. ${ }^{97} 25,275$ (83.3 per cent) of these filings were the result of the filing of an information. 1,221 (4.0 per cent) were the result of a grand jury indictment. In 3,836 cases (12.7 per cent) the defendant pleaded guilty at the preliminary hearing in the lower court and was certified to the superior court for sentencing. Here, too, there are wide variations in practices. In most areas of the state very hittle use was made of the indictment process. Los Angeles County had 2.4 per cent of its filings from indictments, Alameda County had 1.6 per cent; many small counties had none at all. Yet in San Francisco indictments were used in 24.4 per cent of the cases, and in one small county (Placer) the percentage was as high as 34.6 per cent. The use of the certified plea process also varied widely. In Los Angeles only 9.8 per cent and in San Francisco 2.6 per cent of the cases arose in this fashion. Yet in San Diego County the percentage of certified pleas was 51.8 per cent and in Alameda County 44.8 per cent.

What happened to those persons who were formally charged in the superior courts with felonies? 28,922 dispositions were reported for 1960 . 24,816 ( 86.3 per cent) of these were convictions-64.8 per cent on pleas of guilty, 16.0 per cent after trial to the court, and 5.5 per cent after trial by jury. 1,779 ( 6.2 per cent) were acquittals- -4.2 per cent after trial to the court and 2.0 per cent after trial to the jury. 2,156 ( 7.5 per cent) cases were disposed of by dismissals or by being put off calendar. ${ }^{08}$

To complete the picture, it is worth noting what happened to the 24,816 felony defendants who were convicted in 1960. 28.1 per cent were sentenced to prison. 19.0 per cent were sentenced to the county jail. 20.0 per cent were granted probation on condition that they first serve time in the county jail. 24.3 per cent were granted straight probation with no jail conditions. ${ }^{8 \theta}$

What does all this show about the total process in adult felony cases in Cahfornia?

(1) We have no statistical data either on the use of warrants or on the extent to which the prosecutor is consulted prior to arrest. However, all available evidence, including that derived from talking with police officials, suggests that in the overwhelming majority of adult felony cases the de-

07 The figures in this paragraph are taken from $i d$. at 92, table VI-2.

88 Id. at 99 , table VI-8.

89 Id. at 112 , table VI-18. $6.7 \%$ were sentenced to the Youth Authority and $1.9 \%$ were given death sentences or fines or were transferred to a mental hospital. 
cision whether or not to make arrests is made by the police. Certainly the participation of courts through the issuance of warrants is so small that it is insignificant statistically-even if one assumes that judges do in fact screen the police decision when issuing warrants.

(2) The available data tell us nothing about how well the police are performing the function of deciding when to arrest in felony cases. We know nothing about the decision not to arrest. Even concerning the decision to make an arrest, we have remarkably little information. Without some system under which all or some scientific sample of arrests are judicially screened for validity, we liave no way of knowing how inany arrests are legal and how many illegal.

(3) We know that in felony cases police and prosecutors apply quite different standards to the decision to arrest than they do to the decision to charge. In very rough overall terms the difference seems to be that at the arrest-booking stage, the probable cause standard is at such a level that about 1 out of every 2 adults arrested will ultimately be convicted of either a felony or a misdemeanor. At the level of filing complaints 3 out of every 4 charged will be convicted of either a felony or a misdemeanor. To put it another way, out of every 25 charged, only about 4 will be released because of failures of proof, either before or at trial.

(4) We know that police and prosecutors decide to release more than 1 out of every 4 adults arrested on felony charges. We do not know, however, how many of these releases result from demonstrations of innocence and how inany from technical failures of proof, refusals of complamants to prosecute, and other reasons that cast little doubt on guilt.

(5) We know too little about the handling of persons between arrest and charge. Neither the statewide statistics nor individual police department reports deal with sucl matters as the following: Length of time between arrest and charge or release; percentage of arrestees who are released on bail prior to charge; extent of interrogation; frequency of confessions or admissions; and similar matters. However, some information regarding these matters is contamed in the following report of a survey of actual practices in two cities.

\section{III}

TWO-CITY SURVEY

The chiefs of police in two California cities (City $A$ in the 250,000500,000 bracket and City $B$ in the 100,000-250,000 bracket) conducted surveys in 1960 to discover in detail the performance of their own forces in the processing and disposition of persons arrested on felony charges. Special report forms (substantially identical in each city) were devised 
and the members of the detective division in each city were required to complete a form for each arrested person processed by them during a three month period (January-March 1960 in City $A$ and February-April in City $B)$. The original forms completed during this survey and statistical analyses of them were made available to the author by each police department for use in preparing this article.

\section{A. Limitations of the Data}

Before examining the results of these unique surveys, it is important to examine the limitations of the data procured. They may be summarized as follows:

(1) In each city records were completed only for adults who were arrested and booked and then processed by the detective divisions. In City $A$ arrests for narcotics, gambling, and other vice offenses were not included in the survey because they were processed by a special unit separate from the detective division. In City $B$, however, vice arrests were included. Neither city included juvenile arrests. An undetermined number of felony arrests handled without the intervention of the detective divisions were not included. However (aside from vice arrests in City $A$ ) it seems probable that substantially all adult felony arrests of a type that resulted in delay between arrest and charge for purposes of investigation were included. It is assunied (but not known) that in each city the detective divisions in fact completed records on all arrests processed by them.

(2) The records were completed by the detectives themselves with knowledge that they were to be part of a special survey of their practices. It is not known to what extent the fact that the records had to be completed resulted in changing the actual practices of the detectives. However, it seems fair to assume that the completed forms accurately represented the police practices during the reporting period. Each form was signed by a detective and reviewed by a superior officer. They were also examined and checked for discrepancies within the departments in the process of completing the statistical analyses.

(3) The samples were too small to permit valid generahzations from the data received. In particular, the samples did not permit an appraisal of the performance of the police departnients concerned when faced with serious crimes of violence and public pressures for their quick solution.

(4) The data are of only the most limited utility in comparing City $A$ with City $B$, or either of these cities with other cities. Policing problems are determined in large measure by the individual characteristics of the area involved. Here there were marked differences between City $A$ and City $B$. City $A$, for example, had substantial areas of high crime incidence -skid row and slum housing areas. City $B$ was more residential in char- 
acter with very little area that could be described as skid row or slum. These differences were reflected in the 1960 figures for felony crime reports of the seven major offenses plus forgery and check offenses: City $A$ had reports of about 2,317 per 100,000 population, while City $B$ had only 1,863 per 100,000 . Similarly, during 1960 City $A$ had a felony arrest rate of about 721 per 100,000 population, while City $B$ had a rate of only 325 .

\section{B. Results of the Survey}

\section{Arrests}

The survey was not designed to and did not give any information about the circumstances under whicls arrests were made or the incidence of legal and illegal arrests. It did disclose, lowever, some information about the extent to which warrants were used for felony arrests. In City $A, 17$ out of the 399 arrests reported ( 4.3 per cent) were made on warrants. In City $B, 9$ out of 59 (15.3 per cent) were on warrant. In each city the largest group of warrant arrests were made for forgery and bad check offenses6 out of 17 in City $A$ and 6 out of 9 in City $B$.

\section{Processing of Arrested Persons}

The practices of the two police departments involved must be evaluated against the background of the California law with respect to bail in cases wliere arrests are made without warrants. A person arrested on a misdemeanor charge is entitled to be admitted to bail by the officer in charge of any jail in which he is held according to a fixed schedule. ${ }^{100} \mathrm{He}$ can post casls or a surety bond and obtain his release without the need for a court appearance, usually at any time during the day or night after le has been booked into the jail. The statute provides, however, that a person arrested on a felony charge cannot be admitted to bail until bail lias been set by a judge. ${ }^{101}$ In the normal routine in City $A$, bail in felony cases is not set until the prosecutor files a complaint in court and a warrant fixing bail is issued and served on the defendant in jail. For bail to be fixed at an earlier period the defendant may be able to get an attorney or friend to take the initiative for lim and go before a judge for a special setting of bail prior to the filing of a complaint. In City $B$, as a matter of local practice, a bail schedule lias been established for felony cases and bail is taken at the jail without going to the judge for each case. This means that a person arrested on a felony charge in City $B$ may secure his release on bail shortly after he is booked.

101 CaL. Pen. Code $\$ \$ 1269 \mathrm{~b}, 1276$; see 32 Ops. CaL. Atr'y Gen. 84 (1958). For the law prior to the adoption of $\$ 1276$ in 1957, see Gustafson, Bail in California, 44 CALIF. L. Rev. 815 (1956). 
Against this background the surveys disclose some variations in the procedures of the two police departments. In City $A$ it appears that whenever a person is arrested without warrant on a felony charge, he is taken to the city jail and booked for "investigation" of the particular felony. This booking charge appears to be standard practice-at least for all cases assigned to the detective division for processing - and bears no relationship to the extent of the evidence against the defendant. If it is decided to file a complaint against the defendant, then a "final charge" will be made on the records to conform with the complaint. In City $B$ the practice appears to be somewhat different, with most initial bookings being made "on the nose" for the offense suspected. In this department a booking for "investigation" appears to be reserved for those cases where the evidence against the defendant is considered inconclusive at the time of booking.

The original report forms also disclose the existence (but not the extent) of another practice in City $A$. The booking sheet of a person arrested and booked for a misdemeanor may have added to it a "hold" for investigation of a specified felony. For the purposes of the felony charge he is treated as though arrested on such charge and a decision is made either to release the hold or to file a felony complaint. Even though the felony hold is released, the defendant normally will be proceeded against on the misdeineanor charge. The principal reason for this practice appears to relate to bail procedures. The effect of the "hold" is to prevent the defendant from being released on bail under the misdemeanor schedule and to require judicial setting of the bail-thus prolonging in the normal case the period of time in which im-custody investigation may be carried on. The report forms did not disclose a similar practice in City $B$.

This study was not designed to disclose data on the number of cases in which defendants arrested on felony charges were able to secure their release on bail prior to the filing of the complaint. Neither this study nor any other study known to the author gives significant statistical detail regarding the administration of bail in Califorma. However, the original report forms tend to substantiate the general impression gained from interviews with knowledgeable persons that very few defendants in either city obtain their release on bail prior to the filing of the felony complaint. The reason usually is that no bail has been set, or the necessary money is unavailable.

The surveys do give helpful data about police practices in the following areas: Release rate; time between arrest and booking; for those released, time between arrest and release; for those charged, time between arrest and charge.

City A. 137 (34.4 per cent) of the 399 arrests included im the survey 
resulted in releases. The raw data contained in the forms are not adequate for a statistical survey of the reasons leading to the releases. A subjective impression is that about 75 per cent of the releases were because of insufficiency of the evidence to justify charging the defendants. ${ }^{102}$ In a surprisingly large number of release cases-perhaps as high as 20 per cent-the defendant made either a confession or an admission connecting him with the offense. Most of these involved stolen autos or bad checks and the complaining witnesses refused to prosecute on learming the identity of the offender or upon restitution of the property.

City $B .11$ ( 18.5 per cent) of the 59 arrests included in the survey resulted in releases. Inspection of the original forms suggests that 7 of the 11 releases resulted from insufficient evidence to charge the defendant with an offense committed within City $B$. In the other 4 cases the defendants confessed. Two of these 4 were released because the victim refused to prosecute, two because the prosecuting attorney refused a complaint "in the interests of justice."

\section{b. Time from Arrest to Booking}

City $A$. Despite the large area of the city and the necessity of booking all arrested persons into a single jail, delay between arrest and booking was minimal. 115 (28.8 per cent) were booked within an hour of arrest. 346 (86.7 per cent) were booked within 4 hours of arrest. In only 4 cases did the time exceed 7 hours, and these were cases where the arrests took place in other cities or other special circumstances explained the delay..$^{103}$

$C$ ity $B$. Delay in this city was also minimal. The reduction in delay relative to City $A$ is probably attributable to the smaller area covered by City B. 29 (49.0 per cent) were booked within an hour of arrest. 52 (88.1 per cent) were booked within 4 hours of arrest. In only 3 cases did the time exceed 7 hours, and in each of these cases the delay resulted from the arrest being made in another city. ${ }^{104}$

102 It is not meant to imply that in such cases the original arrests were necessarily unwarranted-only that after investigation it was thought there was insufficient evidence to meet the high degree of probability of conviction required by the prosecutor for the issuance of a complaint.

103 In 21 cases the times involved were not specified on the report form. Information concerning the time periods between arrest and booking is generally available in police department files, since arrest reports commonly show both times. However, such forms may not disclose total detention times. $E$.g., a suspect may be interviewed at the police station for a period of time before the officer decides to "arrest" him.

104 The excellent record of these two pohice departments in holding to a minimum custody prior to booking should be compared with practices shown in Chicago before the 1960 scandals and the new administration of the police department there. AMIERICAN CrvIl LIBERTIES UmIoN, Secret Detentron bX the Chrcago Police (1959). 


\section{c. Time from Arrest to Release ${ }^{105}$}

City $A$. Of the 137 persons who were released, the survey showed the following time intervals between arrest and release:

(a) 66 (48.2 per cent) were released within 24 hours after arrest.

(b) 56 ( 40.8 per cent) were held from 24 to 48 hours before release.

(c) 15 (10.9 per cent) were held in excess of 48 hours, the longest period reported being 66 hours. 11 of the 15 cases included in the period of detention one or more week-end days or holidays. These periods of long detention appeared to be primarily the result of skeleton staffs working over week-ends. A person arrested late Friday or early Saturday might be checked briefly on Saturday. But unless this checking resulted in a definite clearance, he would usually be held for investigation on Monday by the regular detectives assigned to the particular type of offense. These detectives would interrogate the defendant to check his story or look for other evidence, and clear with the prosecuting attorney before deciding whether to charge or release.

City $B$. Of the 11 persons who were released, the survey showed the following time intervals between arrest and release:

(a) 5 (45.4 per cent) were released within 24 hours after arrest.

(b) 3 (27.2 per cent) were held from 24 to 48 hours before release.

(c) 3 (27.2 per cent) were held in excess of 48 hours with the longest period reported being 49 hours. Two of these three cases involved persons arrested in another city, the period of custody being about 48 hours after they were brought to City $B$.

\section{d. Time from Arrest to Charge}

City A. 246 were arrested without warrants and later charged. (14 arrests on warrants and 2 charges by federal authorities account for the

105 Compare Los Angeles Police Department, Special Order No. 50 (Dec. 23, 1958) setting forth the following rules governing investigation and release of prisoners:

I. When a person is arrested by an officer of this Department, the investigating officer assigned to the case shall begin the investigation as soon as possible, and continue, or cause the investigation to be continued, until a final disposition is made of the case.

II. The prisoner shall be arraigned or released by the investigating officer without unnecessary delay.

* If the assigned investigator is not available at the time a prisoner is due to be arraigned or relcased, it shall be the responsibility of the watch couninander of the investigating division to effect the arraignment or release.

* If no investigator is assigned it shall be the responsibility of the custodial jailer to insure arraignment or effect release of the prisoner.

III. In no event shall the prisoner be held in custody of this Department longer than forty-eight lours from the time of arrest without having been arraigned, excluding Sundays and holidays. 
remainder of the group charged.) The survey did not make clear whether the time of charge was the time the complaint was signed in the prosecuting attorney's office or the time the complaint was filed with the clerk of the court. ${ }^{100}$ It apparently did not mean the time at which the defendant actually appeared in court to answer to the charge. The following time intervals between arrest and charge were shown:

(a) 119 (48.4 per cent) were charged within 24 hours of arrest.

(b) 63 (25.6 per cent) were charged between 24 and 48 hours after arrest.

(c) 64 (26.0 per cent) were charged after being held in excess of 48 hours. 56 of these 64 cases involved week-end or holiday periods.

City B. 39 were arrested without warrants and later charged. ( 9 were arrested on warrants.) In this department it was made clear that the time of charge was the time the complaint was filed in the prosecuting attorney's office. In addition, the time at which the defendant actually appeared in court was usually given. In 31 out of the 39 cases the complaint was signed in the morning and the defendant appeared in court on the $2 \mathrm{p}$.n. calendar the same day. In 4 cases the complaint was signed in the late morning or afternoon and the defendant appeared in court on the 2 p.m. calendar the next day. In the remaining 4 cases the information on court appearance was not given. The time intervals between arrest and signing of the complaint were shown as follows:

(a) 21 (53.8 per cent) were charged within 24 hours of arrest.

(b) 14 (35.9 per cent) were charged between 24 and 48 hours after arrest.

(c) 4 (10.3 per cent) were charged after being held in excess of 48 hours. 2 of these 4 were cases in which the police took custody of the defendant several hundred miles from City $B$. The other 2 involved arrests made on week-ends. In fact, in 13 out of the 18 cases in which more than 24 hours elapsed between the arrest and the signing of the complaint, the arrests were made on Friday, Saturday, or Sunday.

\section{Interrogation and Confessions}

The survey in the two cities was also designed to elicit information about the extent to which persons arrested were subjected to interrogation and the results of such interrogation. In City $A$ only interrogation by members of the detective division was recorded. Initial interrogation on the street by patrol officers making arrests was not shown. In City $B$ all interrogation, including that of arresting officers, was shown.

108 The practice is to have a warrant with bail fixed in it issued at this point and served on the defendant in the jail, thus making him eligible for immediate release on bail without waiting for the court appearance. 


\section{a. Amount of Interrogation}

City $A$. Interrogation solely by detectives resulted in the following figures for the entire sample of 399 cases surveyed:

(a) 30 minutes or less $197(49.4 \%)$

(b) 30 minutes to 1 hour $99(24.8 \%)$

(c) 1 hour to 2 hours $62(15.5 \%)$

(d) 2 hours to 3 hours $20(5.0 \%)$

(e) 3 hours to 4 hours $10(2.5 \%)$

(f) 4 hours to 6 hours $3(0.8 \%)$

(g) Not interrogated $8(2.0 \%)$

This sample included only 6 arrests for investigation of homicide. In 4 of these cases complaints were filed charging murder; the interrogation time ranged from 30 to 40 minutes in each case. In 1 of the other 2 cases there was 30 minutes of interrogation followed by the filing of a misdemeanor charge. In the other the defendant was interrogated for 4 hours and then charged with falsely reporting a crime.

Also of interest are the data concerning the time of day when interrogation took place. In City $A$ the detective division works primarily during the day and only detective division interrogation was recorded. At a result, out of the 399 cases only 22 persons were interrogated by the detective division between 7 p.m. and 6 a.m. and of these only 9 persons between 9 p.m. and 6 a.m.

City $B$. The data presented below cannot be compared directly with that for City $A$, since in City $B$ the interrogation by arresting officers was included as well as that by members of the detective division. Hence the following table includes all interrogation by police of the entire sample of 59 cases:

(a) 30 minutes or less $16(27.1 \%)$

(b) 30 minutes to 1 hour $13(22.0 \%)$

(c) 1 hour to 2 hours. $21(35.6 \%)$

(d) 2 hours to 3 hours. $3(5.1 \%)$

(e) 3 hours to 4 hours. $3(5.1 \%)$

(f) 4 hours to 6 hours $1(1.7 \%)$

(g) 6 hours to 8 hours

$2(3.4 \%)$

No homicides were included in the sample. As might be expected from the inclusion of interrogation by arresting officers, there was a higher incidence of interrogation during night hours than was recorded for City $A$. 16 persons were interrogated between 7 p.m. and 6 a.m. -11 of these between 9 p.m. and 6 a.m.

Of some interest in disclosing the kind of problem that often gives rise both to delay in charging and to extensive interrogation are the police notes made in conjunction with the case in City $B$ that involved the longest 
delay between arrest and charge ( 78 hours) and the greatest amount of interrogation ( 7 hours, 55 minutes). With reference to the delay in charging the police note read:

The defendant was apprehended in a house at 4:13 A.M., Saturday, February 13th. A man using an identical modus operandi had previously committed several early morning burglaries, and a special plan to apprehend the latter was actually in operation at the time this offense was committed. The subject was extensively interrogated but denied any burglarious intent. He was interviewed by our psychiatrist on Monday. After 78 hours in custody, a complaint charging vagrancy-trespassing was signed on Tuesday norning. (Our string of early morning burglaries stopped.)

With reference to the interrogation the police note read:

The defendant was arrested during the commission of a burglary at $4: 13$ A.M., February 13th. He was questioned for 3 hours 40 minutes immediately thereafter. Later in the day he was questioned by detectives for $2 \mathrm{I} / 2$ hours because he was believed responsible for a string of other burglaries. On February 15th he was questioned for $11 / 4$ hours, and on February 16th, for one-half hour. He admitted responsiblity only for the offense in which he was apprehended. The string of early morning burglaries stopped and we are morally certain, without evidence, that he was responsible for them.

\section{b. Results of the Interrogations}

$C$ ity $A$. The data received from this city were adequate to show the numbers of cases in which confessions or admissions were received and the amount of custody that preceded such confessions or admissions. The data do not show the extent to which the confessions or admissions were essential to ultimate conviction of the persons who made them. The following useful information was developed:

(a) Of the 399 persons arrested, 115 (28.8 per cent) gave confessions and 232 (58.1 per cent) gave either confessions or admissions. ${ }^{107}$ Of the 262 persons who were charged, 106 ( 40.5 per cent) gave confessions and 198 ( 75.6 per cent) gave either confessions or admissions. Of the 137 who were released, 9 gave confessions and 34 gave either confessions or admissions.

(b) Of the 232 defendants who made either confessions or admissions, 38 (16.4 per cent) made them when they had been in custody for 1 hour or less; 100 (43.0 per cent) when they had been in custody 8 hours or less; 183 ( 79.0 per cent) when they lad been in custody 24 hours or less.

$C i t y B$. The survey in this city showed the following with respect to the

107 One limitation on this data for both cities should be emphasized: The individual reporting officers characterized the responses of the defendants as confessions, admissions, or negative. There is no way of knowing what criteria they used for the classification, or even if the various officers used similar criteria. 
numbers of cases in which confessions or admissions were received and the amount of custody that preceded such confessions or admissions:

(a) Of the 59 persons arrested, 36 (61.0 per cent) gave confessions and 52 ( 88.1 per cent) gave either confessions or admissions. Of the 48 persons who were charged, 30 (62.5 per cent) gave confessions and 43 (89.6 per cent) gave either confessions or admissions. Of the 11 who were released, 6 gave confessions and 9 gave either confessions or admissions.

(b) Of the 52 persons who made either confessions or admissions, 39 (75.0 per cent) made them when they had been in custody 1 hour or less; 42 (80.8 per cent) when they had been in custody 8 hours or less; 48 (92.3 per cent) when they had been in custody 24 hours or less.

\section{Dispositions}

Prior to the fall of 1961 there was no requirement in California for the courts to make reports to police concerning the disposition of criminal cases. ${ }^{108}$ As a result, a police department that wished to get such information usually had to bear the expense of securing it from court records or, perhaps, from records in the prosecutor's office. City $A$ did not at the time of this survey routinely obtain dispesition information. City $B$ did collect such information and it was included in the survey for that city.

City $B$. Of the 48 persons who were charged, 31 (64.6 per cent) pleaded guilty, and in 1 case the complaint was dismissed. Of the 16 who pleaded not guilty, 13 were convicted, and 1 was acquitted. In 2 cases dismissals were entered based on search and seizure rulings.

\section{Conclusions: Two-City Survey}

What conclusions can be drawn from this admittedly inadequate samphing? The principal one, perhaps, is that there is a great need for more research and for broader statistical analysis in this area. Police departments, prosecutors, and courts should be encouraged to provide the information necessary to nieasure performance in the handling of arrested persons. Time and money can be usefully employed immediately in extracting and analyzing information already present in police department files. For example, arrest reports and jail records typically contain such information as time of arrest, time of booking, initial booking charge, final charge, and time of release.

The sample presented here suggests that a full scale survey covering a large number of police departments over a substantial period of time might put police practice problems in a substantially different perspective from that given by reading newspaper accounts and appellate opinions. The data on detention time suggest that police performance in good police 
departments is considerably better than has been generally assumed by police critics. The data also suggest that with the application of enough money and manpower, permitting more investigations to be conducted on nights and week-ends, detention times could be substantially reduced even below those shown in the survey.

Perhaps the most interesting aspect of the survey relates to interrogation and confessions. It is useful to know that in the overwhelming percentage of cases interrogation times in these departments were both surprisingly short and surprisingly productive of confessions and admissions. More data of this kind are essential to a realistic determination of the desirability of any proposals to restrict the authority of police to engage in such interrogation. Our system for the trial of criminal cases would be burdened to the verge of collapse if the percentage of guilty pleas were substantially reduced. This survey suggests that a substantial percentage of these pleas results from confessions or admissions given as a result of minimal police interrogation. Of even greater interest would be a survey on a scale broad enough to permit an analysis of interrogation practices and confessions in homicide cases and other cases that, because of public pressure or other reasons, are given more than the routine investigative treatment.

\section{IV}

THE NEXT STEP: SOME AVENUES TOWARD INTELLIGENT REFORM

Undoubtedly there is a large gap between the law governing police conduct from arrest to release or charge and the actual police practice. This article does no more than suggest the complexity of the problems facing courts, legislatures, and administrators in their efforts to narrow the gap. It is vitally important that full consideration be given to all facets of the problems during the process of reform. Reasonable compromise of contending positions will attain for the ordinary citizen maximum freedom from both private and official interference with his life, liberty, and property. The final section of this article suggests some of the avenues that should be explored and some of the questions that need to be answered if this goal is to be reached. ${ }^{109}$

\section{A. Screening}

The data presented in the preceding portion of this article amply demonstrate that our system of criminal courts is orgamized to deal with a situation in which police and prosecutors screen out all but the most clearly guilty before involving the courts. Under present arrest policies, if the

109 For a recent and more detailed discussion of many of the problems treated briefly in this concluding section, see Remington, supra note 44. 
police complied with the law and brought all arrested persons promptly before magistrates the courts would be swamped. Many persons who would otherwise have been released from police custody without the stigma of a court record would be charged and, probably, subjected to the expense and publicity of a preliminary hearing before securing their release. Many others whose guilt could be clearly established through brief investigation while in police custody would go free because of the inability of the police to conduct such investigation. The public would have to pay the very substantial cost involved in employing the large number of additional judges that would be necessary. And, unfortunately, it is by no means clear that the liberties of the ordinary law-abiding citizen would be enhanced as a result. 110

To the author, at least, it is clear that the direction of reform is to regulate, but not to abolish, pohce-prosecutor screening. Of all the questions involved, the most important, and the most difficult, is that of the extent to which police-prosecutor screeming can be shifted from the post-arrest to the pre-arrest stage. Holding constant the present standards under which formal charges are made only when there is a high probability of provable guilt, how far is it possible to conduct the necessary investigation without arrest and custody? How far is it possible to go in this direction without encouraging an even greater incidence of criminal activity than that now plaguing our society? This is a complex factual question to which not even careful research is apt to give answers that rise substantially above the level of guesswork. Perhaps only controlled experimentation in individual cities can give valid answers. But such experimentation would be useful only with the fullest cooperation of all concerned-the municipal authorities would have to provide the money necessary to increase the police manpower and other investigative facilities; the police, prosecutors, and courts would all have to be wholeheartedly committed to honest efforts to make the experiment succeed.

All that can be done here is to suggest the complexities and difficulties. Doubtless there are cases in which police arrest persons who should not have been arrested-persons against whom there is insufficient ground for suspicion (probable cause) to justify such drastic action. Doubtless there

110 Courts have frequently expressed concern about the damage that can be done to an individual if a formal charge in court is placed without adequate investigation. See, e.g., United States v. Vita, 294 F.2d 524, 530 (2d Cir. 1961) ; Goldsmith v. United States, 277 F.2d 335, 344-45 (D.C. Cir.), cert. denied, 364 U.S. 863 (1960) ; Metoyer v. United States, 250 F.2d 30, 33 (D.C. Cir. 1957) ; United States v. Bonanno, 180 F. Supp. 71, 82-83 (S.D.N.Y. 1960); State v. Smith, 32 N.J. 501, 530, 161 A.2d 520, 535 (1960). See also Barrett, Personal Rights, Property Rights, and the Fourth Amendment, 1960 SuP. Cr. REv. 46, 58; Goldstein, Police Discretion Not to Invoke the Criminal Process: Low-Visibitily Decisions in the Administration of Justice, 69 YaLE L.J. 543, 550 n.13 (1960). 
are other cases in which the police should (and could) delay arrest pending further investigation. But there are also cases in which it is not so clear that the interests of society can be served other than by immediate arrests followed by investigation. These are the kinds of cases that must be carefully considered by those interested in reform. They are the cases that, in the judgment of the author, preclude any easy conclusion that police should never arrest until they have sufficient evidence to meet the present high standard of proof for lodging a formal charge with the magistrate. The following examples suggest some of the types of cases involved. ${ }^{111}$

\section{Arrests to Determine Identity of the Suspect}

Consider the following common situations:

(a) Police are alerted that a bank robbery is in progress. On arriving at the bank they see a man run out the door, jump in a car, and drive off.

(b) At three a.m. an officer on patrol sees a man jump from the window of a darkened commercial building and run down the street. The man ignores a command that he halt.

(c) An officer sees a chase with the pursuer yelling "Stop, thief" at the pursued.

What should a policeman do in such situations? If le does nothing, it may turn out that a bank robber or a burglar or a thief has succeeded in escaping, never to be found again. In the first case, suppose lie stops the man. An immediate search of his person may disclose a gun or a packet of bills. Or it may be productive of nothing but increasing outrage on the part of the person stopped. Should he release him then? Or hold him until he has been able to check in the bank and find out what happened and whether descriptions of the robber exculpate the suspect? If he stops the man, searches him, and holds him while checking, he has arrested him. Most courts would doubtless hold that he had sufficient probable cause to inake the arrest and that this arrest would support the search of his person. ${ }^{112}$ Suppose now that the checking demonstrates the person held was a frightened customer imstead of a fleeing robber. Should the policeman be obligated to take the man before a judge im order to get authorization to release him and to relieve himself from potential tort liability? Should the innocent citizen be compelled to stay in custody while the policeman arranges to get him before a judge?

Similar problems exist in the other situations. Is there any reasonable

111 The author wishes to acknowledge assistance in the following analysis derived from an opportunity to examine an unpublished nonograph on arrest practices in Michigan prepared by Professor Wayne R. LaFave from the data compiled by the American Bar Foundation study of the administration of criminal justice in the United States.

112 Cf. Payne v. Umited States, 294 F.2d 723, 725 (D.C. Cir. 1961). 
way to handle such situations short of a brief period of police detention followed either by release, or formal arrest and charge, depending on what the investigation discloses?

\section{Arrests to Check Physical Evidence}

Policemen are often faced with the necessity of deciding what action to take when they come upon a person having possession of movable physical property under suspicious circumstances. The following examples illustrate the situation:

(a) A patrol officer at night observes a car narrowly miss a pedestrian in a cross-walk. He stops the car. The driver gets out, leaving the door open. Flashing his light in the car, the officer sees six loaded gunny sacks on the back seat with a camera protruding from one of them. He knows that several mights before there had been a $\$ 20,000$ burglary at a camera store. The motorist gives his name, his address, identification, and an unconvincing explanation for the sacks. ${ }^{113}$

(b) The owner of a pawn shop phones in a report that a poorly dressed, suspicious-looking imdividual is seeking to pawn an extremely valuable ring.

(c) A reliable informant has told officers that a particular individual is engaged in stealing cases of liquor from a warehouse. Officers see the individual load boxes into his car at a warehouse and drive away. ${ }^{114}$

(d) Officers are told by an informant that a named individual lias at this moment narcotics on his person or in his room. ${ }^{115}$

(e) Officers stop a man they observed speeding througl a red light in an expensive car late at night. The driver gives as his address a skid-row lotel and has no papers that establisl his ownership of the car. He states that the car was loaned to him by a friend. It will be difficult, if not impossible, to check this story and discover whether the car is stolen until the next morning.

What should the policeman do in situations such as these? In the camera case, for example, how could the officer determine whether the sacks contained the cameras stolen from the camera shop? He could not legally search the car without a search warrant except as an incident of the arrest of the driver. Obtaining a searcl warrant would be futile, because once he lets the driver go he knows that the sacks, if they contain the stolen cameras, will not stay in the car awaiting lis legalized search. Is there any practicable solution other than arresting the driver, searching the car, and then, probably, taking the driver and cameras to the police station for the time necessary to make certain whether or not these are the stolen cameras?

\footnotetext{
113 Compare People v. Hyde, 51 Cal. 2d 152, 331 P.2d 42 (1958).

114 Compare Henry v. United States, 361 U.S. 98 (1959).

115 Compare Spurlock v. United States, 295 F.2d 387 (9th Cir. 1961).
} 
All of these cases pose similar problems. Mere identification of the person having in his possession movable property under suspicious circumstances is not enough. If the property is to be available for checking, and for ultimate return to its owner if it turns out to be stolen, it must be taken into police custody. And to accomplish this legally it is necessary to make an arrest. Certainly, in such circumstances, it would not be reasonable to require the police to take the accused before a judge and formally charge him with a crime before checking to see if the goods are stolen. Nor would it be reasonable to require such presentation after police checking had resulted in clearing the accused of suspicion.

\section{Arrests on Descriptions}

Often arrests are made because a person fits the description given by witnesses to a crime. ${ }^{116}$ Suppose, for example, witnesses to a bank robbery agree generally that the robber was a small Caucasian with dark hair wearing a green plaid coat with tan or brown trousers; that he drove off in a dark green Chevrolet, either a 1955 or 1956 model, with mud splattered on the rear hicense plate. This description is flashed to all police cars. Two hours later a policeman observes a man generally meeting this description getting into a dark green 1955 Chevrolet with mud splattered license plates that is parked near a bar with an unsavory reputation. The policeman calls to the man to stop but he ignores the command and drives away.

What should the officer do in such a situation? Let the man go? Stop him and seek by brief interrogation to determine if he might be the robber? If this interrogation gives inconclusive results and the man refuses a request to come to the station for further checking, what then? The normal procedure would be to make an arrest, take the man to the station, and turn him over to the detectives on the robbery squad. They would check his alibi and arrange an identification parade to see if the witnesses could identify him as the robber. If the witnesses failed to identify him, he would be released. If they did identify him, he would be formally charged in court. ${ }^{117}$

In many cases persons who are stopped by police because they meet the description of the person who has committed a crime will cooperate willingly in the process of checking, so that arrests need not be made. But where the suspect refuses such cooperation, is there any reasonable alterna-

116 Compare United States v. Juvelis, 194 F. Supp. 745 (D.N.J. 1961).

117 The courts in the District of Columbia are liaving difficulty in sustaining police detention for the purpose of holding an identification parade in light of the rule in Mallory v. United States, 354 U.S. 449 (1957). See Payne v. United States, 294 F.2d 723 (D.C. Cir. 1961) ; United States v. Meachum, 197 F. Supp. 803 (D.D.C. 1961). But cf. United States v. Vita, 294 F.2d 524 (2d Cir. 1961). 
tive to arresting him and holding him in custody until an appropriate check can be made to see if the witnesses can identify him? And is there any reason to have the suspect brought before a court and charged with a crime prior to making such a check on identification?

The foregoing illustrations suggest that the direction for reform is not the abolition of in-custody investigation, but rather its reduction to the minimum necessary for adequate law enforcement. How is this to be accomphished? There are no easy answers to this question. But answering it must in some fashion be made one of the principal objectives of law enforcement agencies. Police departments should be measured and compared not only in terms of "arrests" and "clearances" and "convictions," but also in terms of their effectiveness in reducing the incidence of arrests and the amount of police custody. Pohce departments should boast of their ability to reduce the percentage of persons arrested who are released without charge. ${ }^{118}$ Such a reorientation in conventional police thinking will not be accomplished casily.

\section{B. Regulating Police Custody}

If we assume that there are situations in which police must be given the power to liold persons in custody for investigation, it then becomes appropriate to focus attention on defining the rules that should govern such custody. Once more we face a host of complex and difficult problems. What is the role of interrogation and what limits, if any, should be imposed on its conduct? When and under what circumstances should the accused be permitted to consult with counsel? Should those persons whose financial resources permit them to purchase bail bonds be permitted to terminate in-custody investigation by securing bail? Are there substantial numbers of persons who might safely be released from custody on their own recognizance during the investigation period? If so, how can these persons be readily identified without time-consuming investigation? Should the law facilitate such releases by permitting the imposition of reasonable and enforceable conditions upon release--such as obligations to appear at definite times and places for interrogation or for identification parades?

\section{A Suggested Program for Legislative Action}

It is not the purpose of this article to explore in detail the various possible avenues for legislative reforn. Many proposals have been made by

118 See Oakland [California] Police Department Monthly Crime Summary, Bull. No. 6011, Nov., 1960: "A study of police dispositions of persons arrested for burglary discloses that in 1960 only $18 \%$ Lave been released without being formally charged. Statewide, the percentage released is $33.3 \%$ for the same offense classification. This limited study demonstrates that quality has not been sacrificed in Oakland law enforcement. The Oakland Police Department policy does not permit arrests on mere 'suspicion'." 
others over the years ${ }^{119}$ and a few statutes now on the books are suggestive of solutions to part of the problems. ${ }^{120} \mathrm{~A}$ much more elaborate and careful examination of the practices and practical problems of law enforcement agencies than that presented in this article is necessary for intelligent legislative action. And some means must be found to secure the cooperation of

119 See, e.g., Hopkins, OUR Lawless Poutce ch. 23 (1931) ; Justice, Premninary Inves-

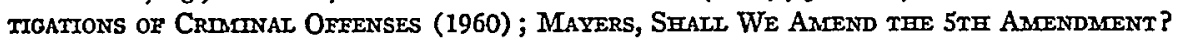
ch. 5 (1959); Orfiedd, Crintnal Procedure From Arrest to Appeat chs. 1, 2 (1947); Beaney, Right to Counsel Before Arraignment, 45 MinN. L. Rev. 771 (1961); Coakley, Restrictions in the Lare of Arrest, 52 Nw. U.I. REv. 2 (1957); Foote, Safeguards in the Law of Arrest, 52 Nw. U.L.REv. 16 (1957); Foote, The Fourth Amendment: Obstacle or Necessity in the Law of Arrest?, 51 J. CRIM. I., C. \& P.S. 402 (1960); Hall, Police and Law in a Democratic Society, 28 IND. L.J. 133 (1953); Inbau, Restrictions in the Law of Interrogation and Confessions, 52 Nw. U.L. REv. 77 (1957) ; Leibowitz, Safeguards in the Law of Interrogation and Confessions, 52 Nw. U.L. REv. 86 (1957); McCormick, Some Problems and Developments in the Admissibility of Confessions, 24 TExAs L. REv. 239 (1946) ; Potts, The Lave of Arrest, 1 Baycor L. Rev. 397 (1949); Warner, The Uniform Arrest Act, 28 VA. L. REv. 315 (1942); Warner, Modern Trends in the American Law of Arrest, 21 CAN. B. Rev. 192 (1943); Wilson, Police Arrest Privileges in a Free Society: A Plea for Modernization, 51 J. Crms. L., C.\& P.S. 395 (1960) ; Note, Some Proposals for Modernizing the Law of Arrest, 39 CaLIF. L. Rev. 96 (1951); Note, 68 YaIE L.J. 1003 (1959). See also Congressional hearings cited note 53 supra. For some suggestions for reform in England that are relevant to the American problem, see Williams, Qnestioning by the Police: Some Practical Considerations, [1960] CRDM. L. REv. (Eng.) 325.

120 The potentialities for direct legislative regulation of police custody are shown by the following provisions of the Juvenile Court Law enacted in California in 1961. See CaL. WELFARE \& INST'NS CODE $\$ \S 625-40$. The following key sections illustrate the approach:

§ 626: An officer who takes a minor into temporary custody under the provisions of Section 625 shall thereafter proceed as follows:

(a) He may release such minor; or

(b) He may prepare in duplicate a written notice to appear before the probation officer of the county in which such minor was taken into custody at a time and place specified in the notice. The notice shall also contain a concise statement of the reasons such minor was taken into custody. He shall deliver one copy of the notice to such minor or to a parent, guardian, or responsible relative of such minor and may require such minor or his parent, guardian or relative, or both, to sign a written promise that either or both will appear at the time and place designated in the notice. Upon the execution of the promise to appear, he shall imnediately release such minor. He shall, as soon as practicable, file one copy of the notice with the probation officer; or

(c) He may take such minor without unnecessary delay before the probation officer of the county in whicb such person was taken into custody and deliver the custody of such minor to the probation officer.

In determining which disposition of the minor he will make, the officer shall prefer the alternative which least restricts the minor's freedom of movement, provided such alternative is compatible with the best interests of the minor and the commumity.

§ 628: Upon delivery to the probation officer of a minor who has been taken into temporary custody under the provisions of this article, the probation officer slaall immediately investigate the circumstances of the minor and the facts surrounding his being taken into custody and shall immediately relcase such minor to the custody 
responsible law enforcement officials and responsible critics of law enforcement practices in the formulation of future policy.

However, as a starting point for future discussions, a general outline will be given of the kind of changes that appear to the author to be worthy of serious study. These proposals will be presented in summary fashion, leaving detailed discussion and justification to some future occasion.

\section{Police-Prosecutor Screening and the Decision to Charge}

The law should (and in California probably does) recognize as legitimate the existing practice in which most screening is done by police and prosecutors. By this method, formal felony charges are lodged only when there is a high probability that guilt can be established. The principal problem to be explored here is how to minimize the use of police custody while investigations are being conducted. To the extent that periods of custody result from deficiencies in police budgets that produce unnecessary administrative delay, some means nust be found to put pressure on local governneents to provide adequate financing. Similar pressure should be applied

of his parent, guardian, or responsible relative unless it appears that further detention of such minor is a matter of immediate and urgent necessity for the protection of such minor or the person or property of another, or unless it appears that such minor is likely to flee the jurisdiction of the court, or unless it appears that such minor has violated an order of the juvenile court.

\$ 631: Whenever a minor under the age of 18 years is taken into custody by a peace officer or probation officer, such minor shall be released within 48 hours after having been taken into custody, excluding nonjudicial days, unless within said period of time a petition to declare him a ward or dependent child has been filed pursuant to the provisions of this chapter or a criminal complaint against him has been filed in a court of competent jurisdiction.

\$ 632: Unless sooner released, a minor taken into custody under the provisions of this article shall be brought before a judge of the juvenile court for a hearing (which shall be referred to as a "detention hearing") to determine whether the minor shall be further detained, as soon as possible but in any event before the expiration of the next judicial day after a petition to declare such minor a ward or dependent child has been filed. If the minor is not brought before a judge of the juvenile court within the period prescribed by this section, he shall be released from custody.

This statute deals carefully with the conduct of both the police officers and the probation officers in the period prior to bringing the juvenile before the court. That this sort of regulation has practical effect is suggested by the following episode. On Septomber 13, 1961, two days before the new law became effective, it was reported that the Board of Supervisors of Alameda County had approved the appointment of two new juvenile probation officers because of the requirements of immediate investigation contained in the new law. The county probation officer was reported to have said that about $64 \%$ of the bookings into Juvenile Hall occur between $6 \mathrm{p} . \mathrm{m}$. and 8:30 a.m., and on weekends. Thus probation staff members will be required on duty during these hours. Under the old law, juveniles taken into custody during the nigbt waited until the staff came on duty next day to make an investigation, or on weekends until Monday. Oakland Tribune, Sept. 13, 1961, p. 14, col.4.

An interesting earher attempt at regulation of police custody generally is found in HAwarI Rev. Laws $\S \S 255-5,255-9$ (1955). 
so that police will see reduction in the incidence of arrests and of police custody as an important objective in their operations. To the extent that in-custody investigation is made necessary by existing laws relating to arrest and searcl,, attention should be given to devising ways of making pre-arrest investigation practically more effective.

\section{Detention for Investigation}

The law should authorize detention for the purpose of investigation under defined and limited circumstances. The following types of limitations are suggested:

(a) Reasonable cause must exist to justify sucli detention.

(b) Detention should be authorized only when reasonably necessary to the completion of an investigation. Detention migint be considered necessary under circumstances like the following:

(1) Where evidence of a crime miglit disappear if the defendant were not detained so that a search could be conducted.

(2) Where the defendant would likely flee and be difficult to locate again if not apprehended at the moment.

(3) Where identification procedures are necessary to determine if the defendant committed the offense-identification parades, photograplis, fingerprints, etc.

(4) Where it is necessary to clieck records, make laboratory tests, interview the complaiming witness, etc., in order to determine if the defendant committed the crime, and the defendant's presence is necessary for sucli procedures.

(5) Where the defendant has given an explanation of his conduct or offered the names of alibi witnesses, time is needed for checking, and the defendant's presence is necessary to such checking.

(6) Where custody of the defendant appears to be necessary to prevent danger to the person or property of others.

(c) The length of the detention should be determined by the standard of what is reasonably necessary to completion of the investigation. An outer limit (say 48 hours) might be enacted, with a provision for securing limited extensions upon a proper showing before a magistrate. ${ }^{121}$

\section{Regulation of Detention}

The law should directly regulate the conduct of investigatory imprisonment. Among the matters that should be specifically dealt with are the following:

(a) The place of detention. E.g., should control of such detention be

121 For a description of the English procedure under which the magistrate may authorize limited periods of detention for the purpose of completing the police investigation, see Devin 94-99. 
shifted from the police to an independent agency charged with enforcing the rules? ${ }^{122}$

(b) The extent to which the defendant is to be permitted to communicate with persons outside the jail should be made clear.

(c) The circumstances under which the defendant is to be permitted access to counsel should be spelled out.

(d) The extent and nature of the opportumity for interrogation by the police should be directly regulated. Whether the defendant is entitled to have counsel present during interrogation should be specifically determined. ${ }^{123}$

(e) Whether bail should be available during the period of reasonable investigation also should be determined.

(f) Some means should be devised whereby the detained person is informed of his legal rights at the outset of the period of detention.

\section{Enforcement of the Rules Governing Detention}

Careful attention should be given to the problems of enforcement. Here new and imaginative solutions are called for. Two possibihties occur to the author. Obviously each of them is subject to legitimate objections and careful and detailed examination should precede any attempt to implement them.

(a) Introduce mto the routine of police operations (at least in urban areas) a responsible independent officer-judicial, quasi-judicial, or administrative-with the duty of supervising police control over persons held in custody. Such an officer might be authorized to explain to each person his legal rights, to decide when and under what conditions such person could be released pending investigation, and to enforce the rules governing interrogation and access to counsel.

(b) Introduce control at the state level through the device of state

122 See Williams, Questioning by the Police: Some Practical Considerations, [1960] Crma.

L. REv. (Eng.) 325, 345-46:

It would ... be a step towards preventing possible abuses if the accused were removed from the custody of the police .... [W] here a local jail is available, it sbould be made a rule that persons arrested should be lodged forthwith in this jail rather than in a police cell. This would mean that the physical safety of the accused person would be the responsibility of a different set of officials from the police. The police could be given a reasonable opportunity to question the accused in private in the prison, but the door would have the usual grid through which a prison warder might occasionally look. Thus the accused person would have some feeling of security against possible illegal violence on the part of the police, and the trustworthiness of confessions would be increased. The arrangement would also be to the advantage of the police because they could more easily refute charges of impropriety.

123 See the illuminating opinion by Justice Traynor concurring in Pcople v. Garner, 57 A.C. 151, 172, 367 P.2d 680, 693, 18 Cal. Rptr. 40, 53 (1961). 
financial assistance made available only to those police departments that demonstrate they are operating in substantial compliance with the governing rules. ${ }^{124}$ Such a solution would require careful definition of the standards to be met and substantial changes in record-keeping in order to minimize the amount of investigation required by the responsible state agency. 